\title{
Microscopic and tomographic studies for interpreting the genesis of desert varnish and the vesicular horizon of desert soils in Mongolia and the USA
}

\author{
Marina P. Lebedeva, Dmitry L. Golovanov, Vasily A. Shishkov, Andrey L. Ivanov, \\ Konstantin N. Abrosimov
}

Marina P. Lebedeva

m_verba@mail.ru

Dokuchaev Soil Science Institute, Russian Academy of Sciences, Pyzhevskiy pereulok, 7, 119017 Moscow, Russia.

Institute of Geography, Russian Academy of Sciences, Staromonetnyj-Pereulok, 29, 119017 Moscow, Russia.

\section{Dmitry L. Golovanov}

Dokuchaev Soil Science Institute, Russian Academy of Sciences, Pyzhevskiy pereulok, 7 , 119017 Moscow, Russia.

Lomonosov Moscow State University, Leninskie-gory, 1, office 2007, 119991 Moscow, Russia.

\section{Vasily A. Shishkov}

Institute of Geography, Russian Academy of Sciences, Staromonetnyj-Pereulok, 29, 119017 Moscow, Russia.

\section{Andrey L. Ivanov}

Konstantin N. Abrosimov

Dokuchaev Soil Science Institute, Russian Academy of Sciences, Pyzhevskiy pereulok, 7, 119017 Moscow, Russia.

BOL. SOC. GEOL. MEX. 2019

VOL. 71 NO. 1

P. $21-42$

http://dx.doi.org/10.18268/BSGM2019v7lnla3

Manuscript received: March 31, 2017. Corrected manuscript received: November 25, 2017. Manuscript accepted: December 14, 2017.

\section{ABSTRACT}

The composition and microfabric of the Av diagnostic surface horizon (crust) and desert varnish of soil formed on various parent materials covering ancien alluvial fans in extremely arid deserts of Central Asia (Trans-Altai Gobi, Mongolia) and North America (Mojave, USA) are analysed. Application of a wide range of methods - morphological and micromorphological descriptions, scanning electron microscopy, electron microprobe analysis and microtomography, together with traditional physicochemical methods - has shown that desert varnish retains the same composition and relative contents of elements $(\mathrm{Fe} / \mathrm{Ti}$ and $\mathrm{Mn} / \mathrm{Ba}$ ) independently from the initial composition of parent materials and geographical location of the studied regions. The absolute dominance of isolated closed (vesicular) pores, identified by micromorphology and confirmed by microtomography, can account for specific hydrophysical properties of the crust horizon; that is, low water-holding capacity and permeability. We explain both phenomena of desert pedogenesis - light-coloured crust horizon and dark-coloured desert varnish - the burst of microbiological activity and physicochemical processes after rare but heavy showers during the hot season. The development of iron-depleted zones around pore is considered the evidence of that phenomenon Consequently, we propose that $\mathrm{Mn}^{2+}$ undergoes mobilization within the crust horizon, followed by it upward migration with capillary and film moistur flows, against the gravity gradient to the surface of desert pavement with its subsequent fixation at the oxygen barrier. The processes of sulphate reduction are indirectly confirmed by the mobilization of $\mathrm{Ba}^{2+}$ which is immobile in the presence of sulphates. These elements ( $\mathrm{Mn}$ and $\mathrm{Ba}$ ) accumulate within the lower part of two-laver films. These films are located in microcavities on the upper sides of rock fragment of desert pavements in the studied regions. Films on lower sides of rock fragments and the upper part of those two-layered films are enriched in $\mathrm{Fe}$ and $\mathrm{Ti}$, and therefore acquire reddish-brownish colours. Despite its transitory character, the process, which we sugges to call 'cryptosolodization', includes five stages: (1) Fe, $\mathrm{Mn}$ and sulphate reduction with mobilization of $\mathrm{Ba}^{2+}$ from $\mathrm{BaSO}$, (2) precipitation of $\mathrm{FeS}$ and migration of $\mathrm{Ba}^{2+}$ and $\mathrm{Mn}^{2+}$ to the stone surface, (3) coprecipitation of $\mathrm{Ba}$ and $\mathrm{Mn}$ at a combined oxygen-sorption barrier, (4) oxidation of $\mathrm{S}^{2-}$ to $\mathrm{SO}^{2-}$ with mobilization of $\mathrm{Ti}^{2+}$ from $\mathrm{TiO}_{2}$ and (5) oxidation of $\mathrm{Ti}^{2+}$ and $\mathrm{Fe}^{2+}$ and their coprecipitation in the form of oxides/ hydroxides $\mathrm{TiO}_{2}$ and $\mathrm{Fe}(\mathrm{OH})_{3}$,

Keywords: desert soils, micromorphology, pedogenesis, mechanisms of development of desert varnish.

\section{RESUMEN}

El artículo analiza la composición y microestructura del Horizonte vesicular Av (Aye), que consiste en la corteza superficial diagnóstica y el barniz del desierto (laca) de suelos, formados sobre diferentes rocas madres y llanuras fanaluvial y antigua en condiciones extremadamente áridas de Asia Central (Transaltai Gobi, Mongolia) y América del Norte (Mojave, Estados Unidos). Se aplicó una amplia gama de métodos. Entre ellos, descripciones morfológicas y micromorfológicas, microscopía electrónica de exploración, análisis electrónico de microsondas y microtomografia, y también los métodos fisicos y químicos tradicionales. Los datos mostraron que laca del desierto (barniz del desierto) tiene la misma composición y la relación relativa de los dementos ( $\mathrm{Fe} / \mathrm{T}$ y $\mathrm{Mn} / \mathrm{Ba}$ ) independientemente de la composición inicial de las rocas madres y de la ubicación geográfica de las regiones estudiadas. Las propiedades hidrofisicas específicas del horizonte cortical superficial, sobre todo su baja permeabilidad al agua, pueden explicarse debido al dominio absoluto de los poros cerrados (vesiculares) aislados identificados por la micromorfología y confirmados por la microtomografia. Explicamos el proceso de formación de suelos -formación conjunta de la corteza ligera, superficial y vesicular y también la laca oscura del desierto (barniz del desierto)- como un mecanismo hidrofisico-biogeoquímico causante de un aumento de la actividad microbiológica y procesos fisico-químicos después de las lluvias raras y fuertes en temporada calurosa. La evidencia de este fenómeno radica en la evolución de las zonas empobrecidas de hierro alrededor de los poros. Al mismo tiempo, $\mathrm{Mn}^{2+}$ está sujeto a la movilización en el horizonte de la corteza y luego se mueve hacia arriba a la superficie con flujos de humedad capilar y de película contra el gradiente gravitacional seguido de la fijación en la barrera de oxígeno. La recuperación de sulfatos (sulfatreducción) se confirma indirectamente mediante la movilización de $\mathrm{Ba}^{2+}$, que se encuentra inmóvil en la presencia de sulfatos. Estos elementos (Mn y Ba) se acumulan en la parte inferior de las películas de doble capa, las cuales están en los microcavidades sobre los lados superiores de los fragmentos de roca del puente desértico en las áreas investigadas. Las películas sobre los lados inferiores y la parte superior de los fragmentos de roca, están enriquecidas con $\mathrm{Fe}$ y $\mathrm{Ti}$ y, por lo tanto, adquieren colores rojizos. Sugerimos llamar a este proceso 'criptosolodización', a pesar de su carácter a corto plazo(explosivo). Incluye 5 etapas: (1) recuperación de $\mathrm{Fe}, \mathrm{Mn}$ y sulfatos con la movilización de $\mathrm{Ba}^{2+}$ de $\mathrm{BaSO}_{4}$, (2) deposición de FeS y migración de $\mathrm{Ba}^{2+} y$ $\mathrm{Mn}^{2+}$ a la superficie de la roca, (3) coprecipitación de Ba y Mn en la barrera combinada de oxígeno-sorción, (4) oxidación $S^{2-}$ a $\mathrm{SO}_{4}^{2-}$ con la movilización de $\mathrm{Ti}^{2+}$ de $\mathrm{TiO}_{2}$ y (5) la oxidación $\mathrm{Ti}^{2+}$ y $\mathrm{Fe}^{2+}$ y su coprecipitación en forma de óxidos/hidróxidos $\mathrm{TiO}_{2}$ y $\mathrm{Fe}(\mathrm{OH})_{3}$

Palabras clave: suelos desérticos, micromorfología, formación del suelo, mecanismos del desarrollo de barniz desértico y el horizonte vesicular (cortical). 


\section{Introduction}

Desert soils occupy approximately 46.1 million square kilometers, or $31.5 \%$ of the Earth's surface (Dregne, 1976). In Asia, they constitute about $33 \%$ of the total area; in North America, $18.5 \%$.

The desert varnish and the vesicular crust horizon are distinctive morphological features of desert landscapes, and generally recognized features of desert pedogenesis. Various symbols are used to designate specific surface horizons of extremely arid soils. Since 1958, surface vesicular horizons have traditionally been designated as Av (vesicular) horizons (Springer, 1958). According to the World Reference Base for Soil Resources (WRB) (2014), this surface horizon has yermic diagnostic properties (earlier, it was identified as a yermic diagnostic horizon) designated by the yermic qualifier (ye) of desert soil subgroups in different reference soil groups (WRB, 2014). Regarding Soil Taxonomy, it has recently been suggested (Turk and Graham, 2011, 2014) that a vesicular horizon (epipedon) should be added to this classification system. In the absence of desert pavement, it corresponds to the nudiyermic (ny) qualifier. Yermic properties are diagnosed by the presence of a pavement and/or a vesicular layer in combination with aridic properties reflecting the activity of aeolian processes, a low humus content, and a high $(>75 \%)$ base saturation (WRB, 2014). In the study of extremely arid soils of Kazakhstan (Lebedeva et al., 2015), these horizons were referred to as vesicular crust horizons.

Currently, there is a great international interest in the problem of genesis of the Av vesicular horizon (synonym: vesicular crust, which is often used in the literature) of arid soils, because it is considered an indicator of degradation or desertification of arable soils, as described in the review by Pagliai and Stoops (2010). However, most of the published studies concern the microfabric of surface horizons in the soils of subtropical deserts. Much less is known about the extremely arid soils and their micromorphological features in the subboreal zone of Central Asia (Gunin, 1990; Mees and

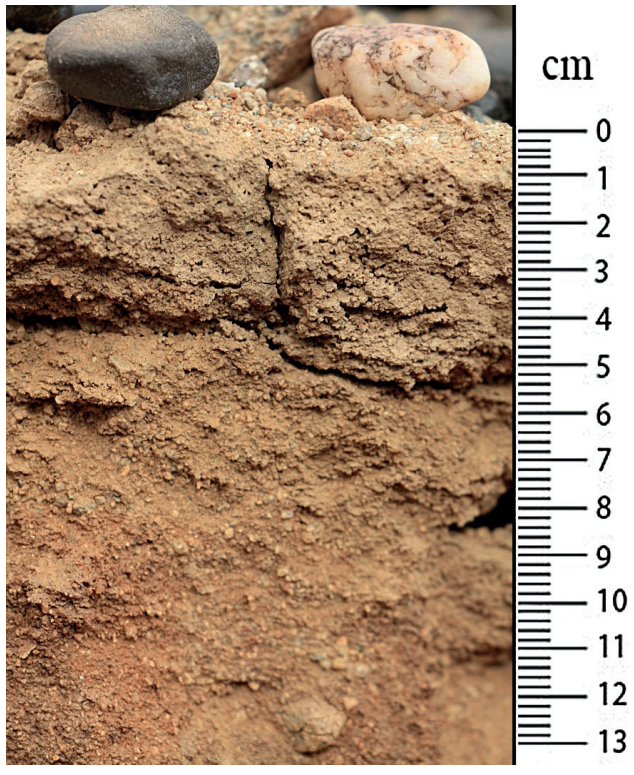

a)

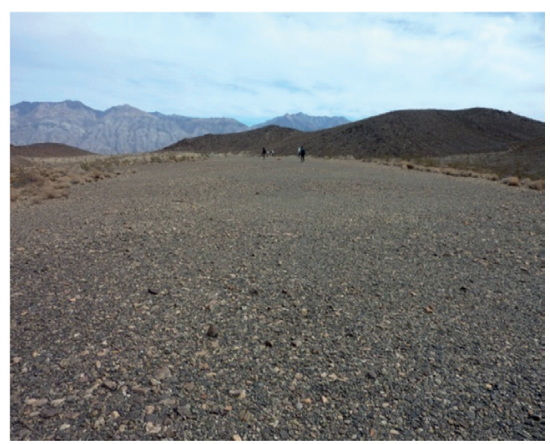

b)

Figure 1 The Mojave Desert: a) the profile of extremely arid soil: desert pavement rock fragments of various colours at the surface, underlain by soil horizons as follows: Av $(0-5 \mathrm{~cm})$, ABvky (5 - $8 \mathrm{~cm}$ ), Btky (8 - $13 \mathrm{~cm}$ ) (pit PAN - 28); b) the level surface of an ancient piedmont plain with desert pavement.

Singer, 2006; Lebedeva et al., 2009; Gerasimova and Lebedeva, 2010).

The upper fine-earth horizons under gravelly desert pavements are characterized by a high density (for that reason, they are referred to as crusts) and by the predominance of isometric vesicular pores. The contents of fine silt and clay particles in the surface fine-earth horizons are considerably higher than in the underlying horizons. This is often explained by the aeolian input of fine particles with their accumulation under 


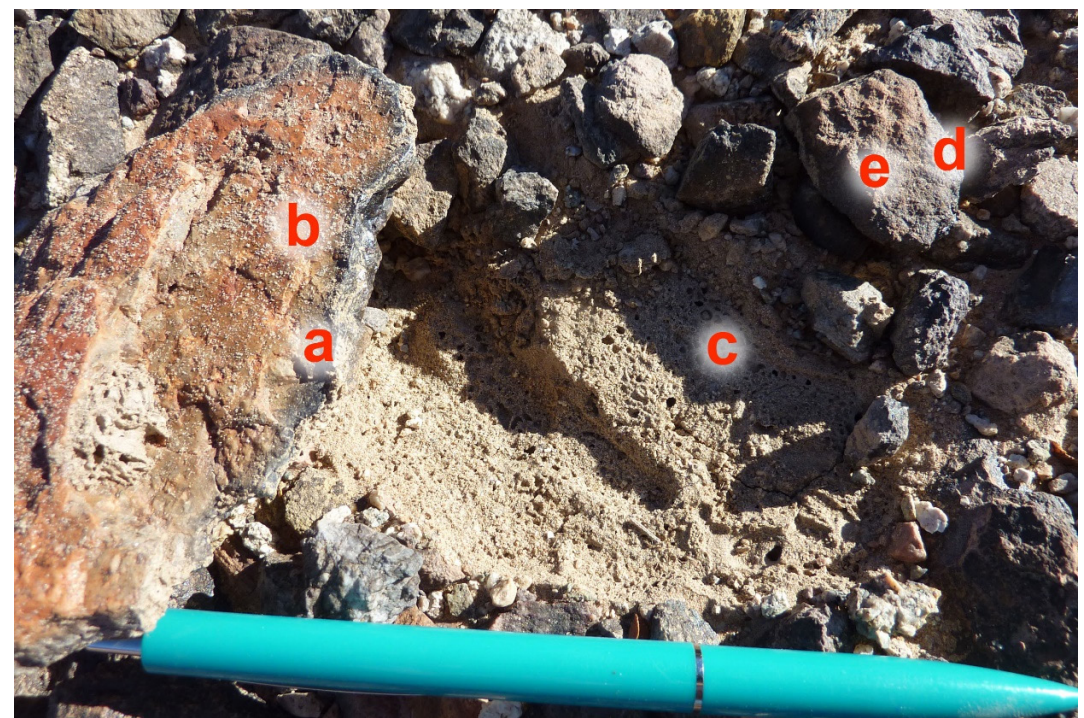

Figure 2 Colour variations in films on rock fragments from desert pavements of ancient piedmont plains of the Mojave Desert (pit PAN28); the rock fragments are set in the fine-earth material of the Av horizon: (a) varnish at the edge of the lower side of broken stones; (b) the brownish-red lower surface of broken stone "sealed in" Av horizon; (c) horizon, opened after the raising of broken stone; (d) the darker selvedge of the broken stone surface; (e) the lighter central part of the broken stone surface.

the scattered gravels and coarser fragments of the desert pavement (Evstifeev, 1977, 1980; Pankova, 1992; Glazovskaya and Gorbunova, 2003; Lebedeva et al., 2009, 2015; Pankova and Gerasimova, 2012; McDonald et al., 2014). The allochthonous nature of aeolian dust in the upper horizon of extremely arid soils of Mongolia was confirmed by mineralogical studies of the clay and silt fractions (Chizhikova et al., 1988).

The study of desert varnish on rock fragments has a long history. This specific feature was first described by Humboldt in 1852 (cited by Perry and Kolb, 2003); later, it attracted attention of Darwin (1860). According to Dorn (2009), there are different types of desert varnish films (coatings, cutans) depending on their composition, with the following principal constituents - clay minerals, silt, calcite, iron and manganese oxides, silica and trace elements. The concentrations of iron and manganese oxides predetermine the colour variations in such films - from orange to virtually black (Potter and Rossman, 1977, 1979; Krinsley et al., 1995; Dorn, 2009).

The genesis of desert varnish is most commonly explained by weathering of rock minerals with the participation of epilithic and endolithic microorganisms (Glazovskaya, 2002; Mergelov et al., 2012). Another common explanation is the accretion of fine particles on the rock surface with further cementation of the accumulated material by iron and manganese oxides with the participation of lithobionts (lichens, cyanobacteria and other organisms) (Friedmann and Weed, 1987; McKeown and Post, 2001; Perry et al., 2006; Lebedeva and Shishkov, 2016).

Some cases of layered desert varnish were reported, where the development of a complex microstratigraphic sequence of such layers (microlaminations) was explained by changes in climatic conditions (Liu and Broecker, 2007, 2008; Dorn, 2009).

Arid soils with a vesicular crusty horizon are widespread in the US deserts. They have been studied in detail, including the studies in the Mojave Desert (Blackburn, 1975; McDonald, 1994). The analysis of a great number of soil profiles $(>1000)$ from the Mojave Desert showed that the thickest vesicular horizons are developed under desert pavement on piedmont plains with the age of more than $40 \mathrm{ka}$ (McFadden et al., 1986, 1998; McDonald, 1994; 


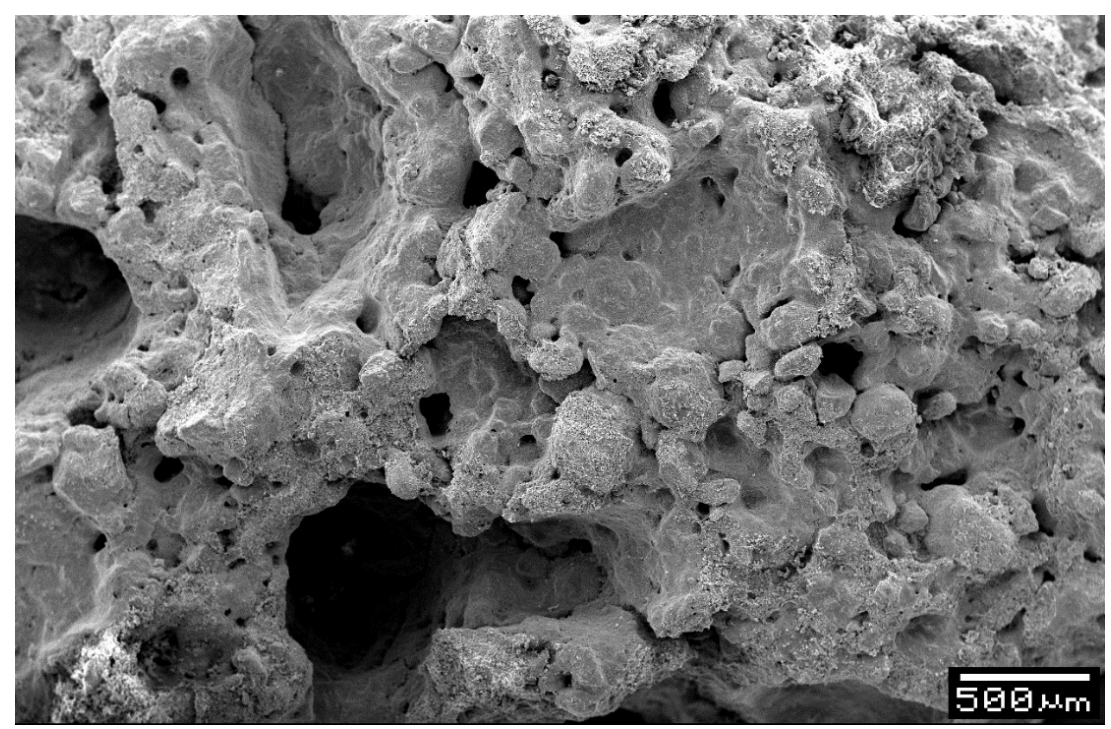

Figure 3 The ancient surface of the Av horizon with pores covered by 'amorphized' clay coatings (Gobi Desert, Mongolia; SEM) (LebedevaVerba et al., 2009).

McDonald et al., 2014). Likewise, a clear vesicular porosity is consistently present under desert pavement with well-developed desert varnish in the Gobi Desert. The vesicular pores have larger sizes, while the surface horizon has lighter (paler) colour compared to the underlying horizons (Evstifeev, 1977, 1980; Lebedeva-Verba et al., 2009).

The aim of this article is to present a new possible mechanism of the development of desert varnish associated with processes in the Av horizon.

\section{Materials and methods}

\subsection{MATERIALS}

Extremely arid soils in the Mojave and Trans-Altai Gobi deserts located on different continents and in different climatic zones (subtropical and boreal zones, respectively) were studied.

During the field trip of the International Union for Quaternary Research (INQUA) Project Group RAISIN to the Mojave Desert in 2014, samples from the desert pavement and vesicular crust horizon were taken on the most ancient alluvial fans of the three most ancient (Early and Middle Pleistocene) piedmont plains in the areas devoid of higher plants (McDonald et al., 2014). This is, in the eastern part of the desert at the foot of the Providence Mountains (pit P-18, 53-65 ka), on the Cima volcanic field (pit Cim on the lava flow of 75-85 ka in age), and in the south-western part of the desert in the Panamint Valley (pit PAN-28, 75-85 ka). Detailed information on these pits is given in the field guide (McDonald et al., 2014). Fragments of volcanic rocks predominated in the composition of desert pavements.

The desert pavements were formed by felsic volcanic rocks (spherulitic rhyolite or quartz-rich rhyolite (aporhyolitic microquartzite)) in both deserts, except for the Cima volcanic field with a predominance of olivine basalts.

Their microscopic features were compared with the features of desert varnish and vesicular crust (Av) horizon from the Gobi Desert, where the samples were collected by the authors and E.I. Pankova. Two extremely arid soils (pits 10 and UG-24) on proluvial sediments with a considerable admixture 
Table 1. The main micromorphological features of the topsoils.

\begin{tabular}{l|c|c|c|c|c|c|c|}
\multirow{2}{*}{ Desert } & \multirow{4}{*}{ pit } & \multicolumn{4}{|c|}{ Voids } & $\begin{array}{c}\text { Groundmass } \\
\text { c/f related } \\
\text { distribution }\end{array}$ & $\begin{array}{c}\text { Micromass b- } \\
\text { fabric }\end{array}$ \\
\cline { 2 - 8 } & & $\mathbf{v}$ & pl & pv & ch & fm-op & gs-cr \\
\hline Gobi & 10 & +++ & + & + & + & fm-op & gs-cr \\
\hline (Mongolia) & UG-24 & +++ & + & ++ & + & cr & cr \\
\hline Mojave & P-18 & +++ & - & + & + & cp & gs-cr-ss \\
\hline (USA) & PAN-28 & +++ & ++ & + & + & sp & gs-cr \\
\hline
\end{tabular}

\begin{tabular}{|c|c|c|c|c|c|c|c|c|c|}
\hline \multirow{3}{*}{ Desert } & \multirow{3}{*}{ pit } & \multicolumn{8}{|c|}{ Pedofeatures } \\
\hline & & \multicolumn{2}{|c|}{ carbonate } & \multirow[b]{2}{*}{ clay } & \multirow[b]{2}{*}{ inter } & \multirow[b]{2}{*}{$\mathrm{Fe} / \mathrm{Mn}$} & \multirow{2}{*}{$\begin{array}{c}\text { matrix } \\
\text { Impregnation }\end{array}$} & \multirow{2}{*}{$\begin{array}{c}\text { matrix } \\
\text { depletion }\end{array}$} & \multirow{2}{*}{$\begin{array}{c}\text { organic } \\
\text { matter }\end{array}$} \\
\hline & & mi & $\begin{array}{l}\text { other } \\
\text { types }\end{array}$ & & & & & & \\
\hline \multirow{2}{*}{$\begin{array}{l}\text { Gobi } \\
\text { (Mongolia) }\end{array}$} & 10 & $\mathrm{w}$ & - & $c-p$ & - & $\mathrm{nt}(++)$ & + & +++ & $\mathrm{clr}$ \\
\hline & UG-24 & $\mathrm{m}$ & crs & $\mathrm{c}$ & ++ & nd $(+)$ & + & - & $\mathrm{p}$ \\
\hline \multirow{3}{*}{$\begin{array}{l}\text { Mojave } \\
\text { (USA) }\end{array}$} & P-18 & $\mathrm{W}$ & - & $\mathrm{p}-\mathrm{c}$ & - & nd $(+)$ & + & + & $\mathrm{p}$, or \\
\hline & PAN-28 & $\mathrm{s}$ & $\mathrm{im}$ & $p-c-d f$ & - & nd $(+)$ & +++ & ++ & $\mathrm{p}$, or \\
\hline & $\mathrm{Cim}$ & $\mathrm{m}$ & $\mathrm{nt}$ & $c-p$ & ++ & nd $(+)$ & + & - & or \\
\hline
\end{tabular}

,,,-++++++ Indicate increasing frequency of pedogenic features: - = absent, + = rare (locally in separate zones), ++ $=$ common, $+++=$ abundant.

Void: $\mathbf{v}=$ vesicular, $\mathrm{pl}=$ planes, $\mathrm{pv}=$ packing voids, $\mathrm{ch}=$ chamber .

Groundmass $\mathrm{c} / \mathrm{f}$ related distribution: $\mathrm{fm}=$ fine monic, $\mathrm{sp}=$ single spaced porphyric, $\mathrm{dp}=$ double porphyric,; $\mathrm{cp}=\mathrm{close}$ porphyric,; op = open porphyric.

Micromass: b-fabric - $\mathbf{c r}=$ cristallitic, $\mathbf{s s}=$ stipple speckled, gs $=$ granostriated

Pedofeatures: $c$ = coating; $p$ = papule (fragment of clay coating); inter = intercalation; im- impregnation; $d f=$ deformed pedofeatures; $\mathbf{m i}=$ micrite in groundmass (degree of impregnation: $\mathbf{w}=$ weakly; $\mathbf{m}=$ moderately; $\mathbf{s}=$ strongly); nt = typic nodule; nd = dendritic nodule; crs = crystal intergrowths;

Organic matter: $c l r=$ cell residue, $\mathbf{p}=$ punctuations, or $=$ organ residue.

of red-coloured Cretaceous and Paleogene saline rocks were studied on a gentle southern slope of the Tsagan-Bogdo Mountains (Gobi Tien Shan). Detailed descriptions of characteristic microfeatures of these two soil profiles have already been published by the authors: pit 10, Lebedeva et al. (2009); pit UG-24, - Lebedeva et al. (2016). In addition, the microscopic features of desert varnish on two rock fragments from desert pavement of pit 213 were examined. According to Pankova (1992), the soil profiles exposed in pits 10 and 213 were genetically similar.

All the studied soils were classified according to the WRB system (2014) as Skeletic Luvisols (Aridic, Cutanic) with horizons Avk-ABvk-Btky-BCkyCBky (Figure 1a).
A specific feature of the arid climate of the Gobi Desert is its high continentality, with the soil freezing depth of $60-100 \mathrm{~cm}$ and occasional rainfalls in summer (Pankova, 1992). In the Mojave Desert, the soils do not freeze, because mean January temperatures rarely fall below $0^{\circ} \mathrm{C}$ (except for the valleys, where they may be as low as $-7^{\circ} \mathrm{C}$ ), and precipitation mainly takes place in autumn and winter. In summer, the temperature of the soil surface reaches $54^{\circ} \mathrm{C}$ and more, with the daily amplitude of temperatures up to $26^{\circ} \mathrm{C}$; therefore, the role of condensational moisture is very important in the hot summer months.

The extreme aridity of the studied territories is clearly reflected in the character of vegetation. On the studied piedmont plains with hamadas, 


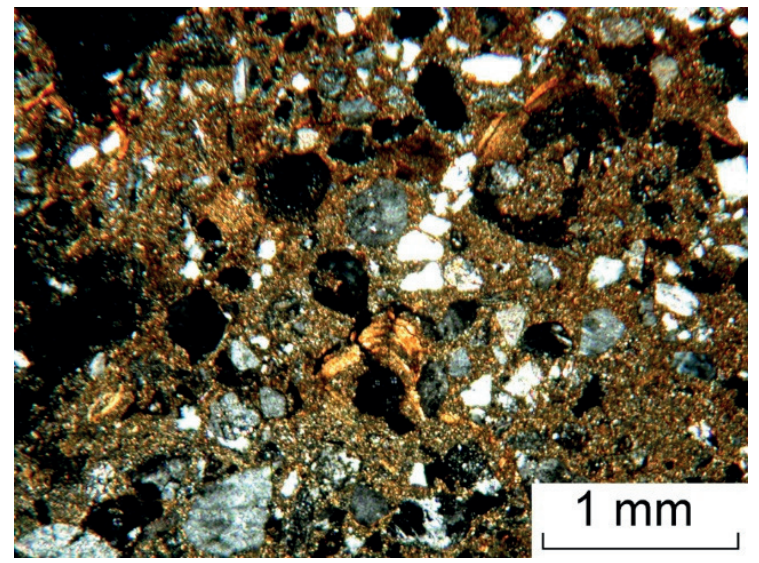

a)

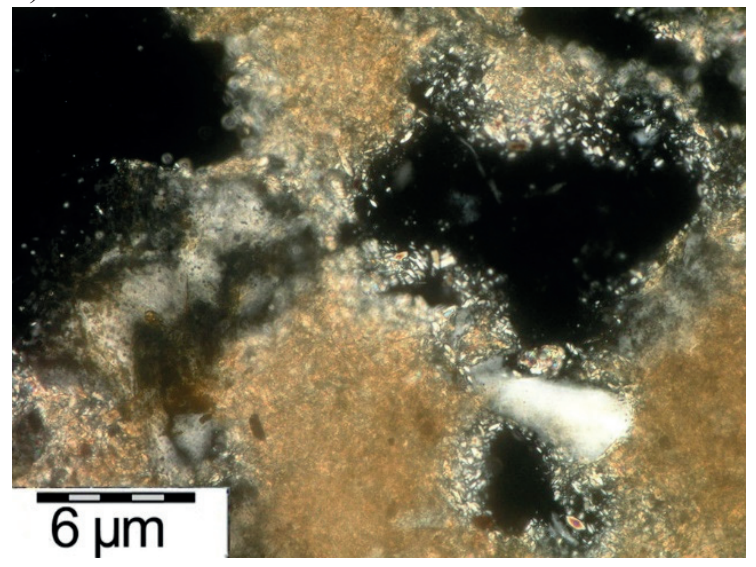

c)

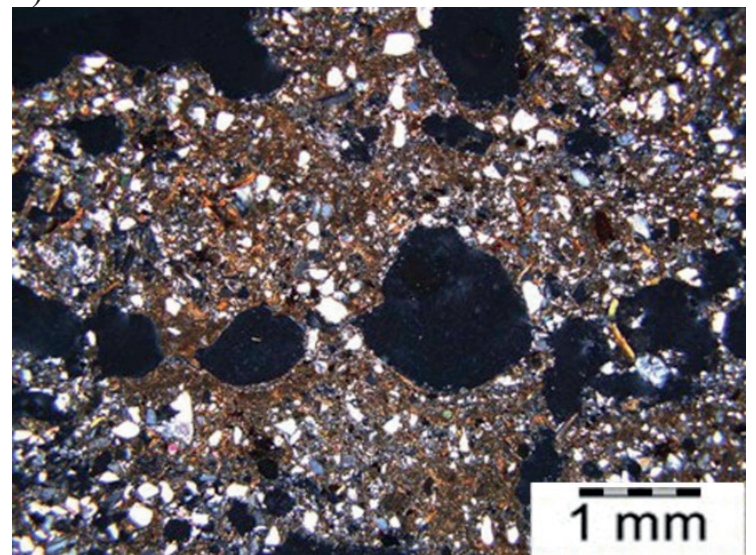

e)

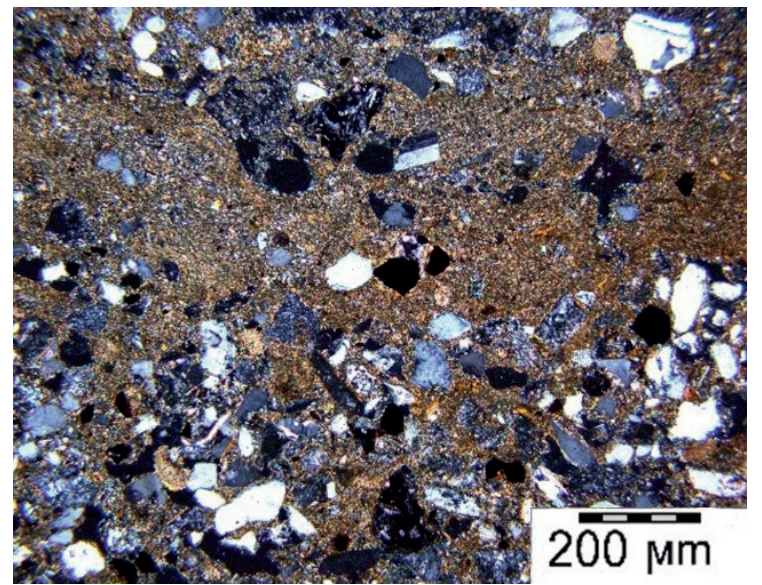

b)

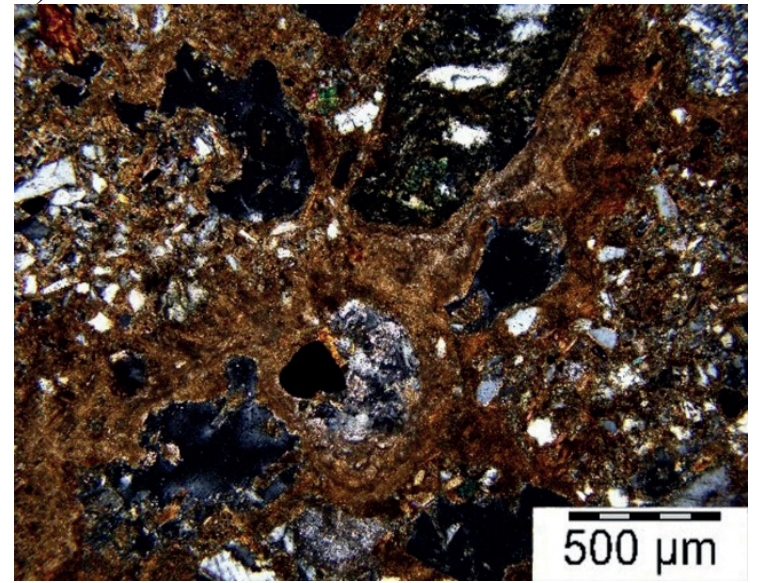

d)

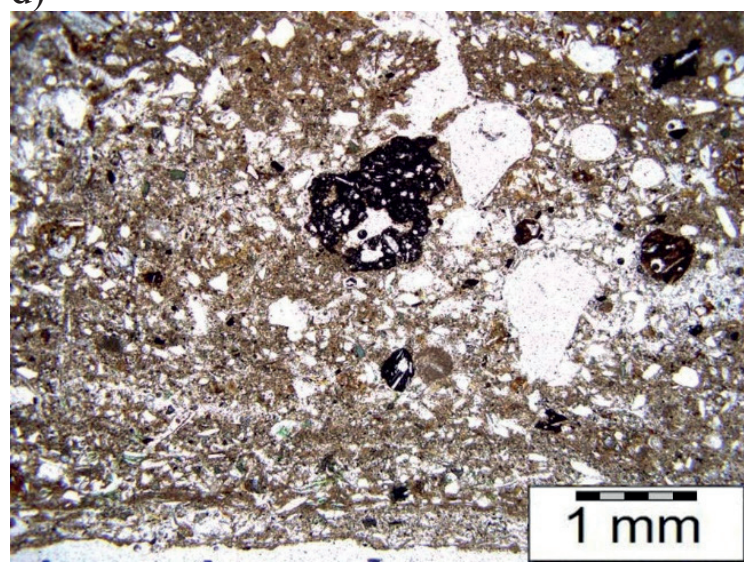

f)

Figure 4 The microfabric of the Av horizons under the pavements in extremely arid deserts of Gobi (a - c) and Mojave (d - f): (a) predominance of vesicular pores with laminated clay coatings in weakly calcareous sandy-clayey material (pit 10, XPL); (b) vertical heterogeneity of distribution of sand, silt and clay particles (pit UG-24, PPL); (c) iron depletion pedofeatures around pores within groundmass (pit 10, XPL); (d) large vesicular pores in clayey calcareous material, inclusions of fragments of sandstone and calcareous rocks, clay intercalations (pit PAN 28, XPL); (e) large vesicular pores in silt-clay material, an abundance of fragments of clay coatings (pit P18, XPL); (f) microlayered distribution of clay particles within silty material, vesicular pores near highly ferruginous small fragments of olivine basalts (pit Sim, PPL). 


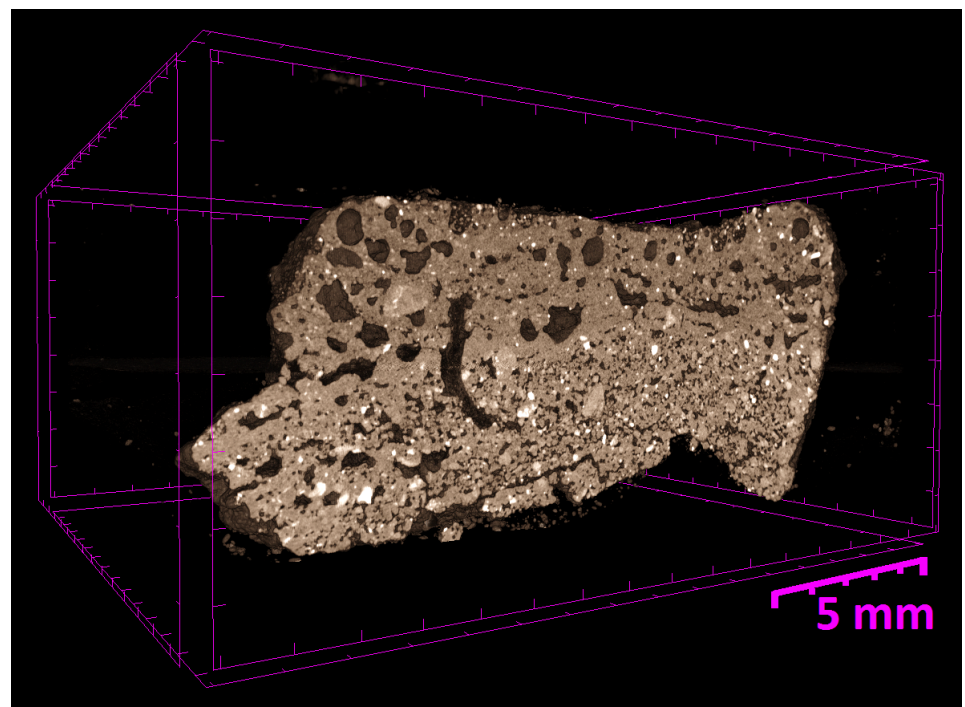

Figure 5 The 3D model of the crust horizon structure. Vertical cross-section through the centre. Pores are dark and mineral grains are light brown or white.

higher plants are absent (Figure 1b). According to Zolotokrylin (2003, 2008), the aridity effect can be enhanced by desert pavements. During the summer, due to the black colour of coatings the surface of desert pavements is heated stronger than the surface of loamy and sandy substrates.

\subsection{METHODS}

Thin sections from rock fragments and from the vertically oriented undisturbed samples (soil monoliths) of the surface soil horizons were prepared in the Laboratory of Mineralogy and Micromorphology of Soils of the Dokuchaev Soil Science Institute by M.A. Lebedev. As the surface horizons had a limited thickness, their thin sections had an area of only $2-4 \mathrm{~cm}^{2}$. These thin sections were prepared in four replications. Micromorphological examination of thin sections was performed with an Olympus BX51 optical microscope equipped with an Olympus DP26 camera. Descriptions were made with the use of international guidelines (Stoops, 2003).
A submicroscopic study was performed using a JEOL JSM-6610LV scanning electron microscope with an INCA Energy X-ray microanalyzer. Additionally, we mapped the patterns of element distributions in the loci with morphologically pronounced cross-sections of desert varnish in the cut rock faces. Special attention was paid to distribution patterns of iron and manganese in the studied thin sections. To supplement the results of morphological observations (as the mapping of the elements of microstructure does not give us information on the real concentrations of the elements), microprobe X-ray spectroscopy was performed, especially, in the loci with high concentrations of iron or manganese.

A microtomographic study of the soil structure was performed on the SkyScan 1172 microtomograph at the V.V. Dokuchaev Soil Science Institute, at image resolution of $5 \mu \mathrm{m}$ per pixel. This non-destructive method allows us to confidently determine the internal structure of soil samples, separate pores and the solid phase (up to separate structural formations - individual 


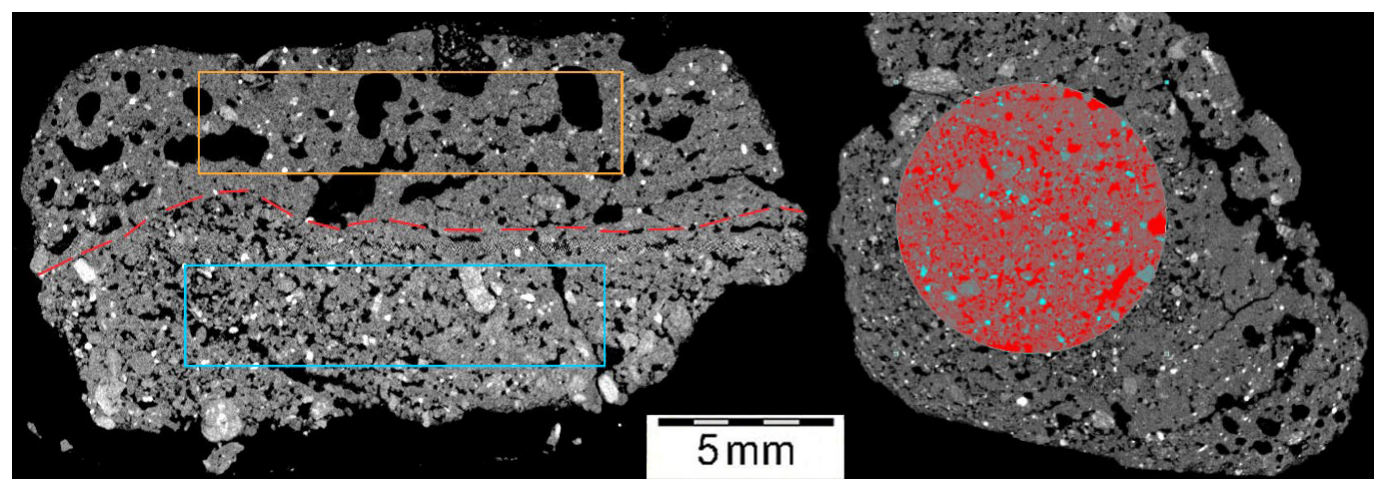

Figure 6 The 3D shapes used in calculating porosity and solid phase parameters per volume unit (Gobi, Mongolia). Left - a vertical cross-section with marked (red) boundary between the upper and the lower parts of the sample, where selections are marked in orange and blue. Right - a horizontal cross-section fragment with one of selected shapes (view from above, marked in red).

microaggregates, concretions, mineral grains, etc.) with a high degree of reliability. Tomographic data were processed in CTvox software (the volume structure of the sample) and CTan (volume morphometric values).

General chemical and physicochemical properties of compared soils were estimated from published data (Pankova, 1992; McDonald et al., 2014).

\section{Results}

\subsection{MAGRO-, MICRO-, AND SUBMICROMORPHOLOGY OF THE AV HORIZON}

\subsubsection{MACROFABRIC OF TOPSOILS}

All the Av horizons studied under desert pavement, compared to underlying horizons, were characterized by a clear vesicular porosity, medium compaction, and a light colour (most often, whitish pale) (Figures 1a, 2).

\subsubsection{MICRO- AND SUBMICROFABRIC OF TOPSOILS}

Micromorphological analysis (Table 1) showed that high amounts of isolated round pores could be present in horizons with different contents of salts and carbonates, different degrees of development of clay coatings on pore walls and different degrees of vertical heterogeneity of coarse fraction contents. The scanning electron microscopic analysis revealed that walls of many pores are covered by very thin, dense and non-layered clay coatings, invisible under an optical microscope (Figure 3). The comparative analysis of many thin sections from extremely arid soils demonstrated that round-shaped vesicular pores occur mostly within microzones with fine monic coarse/fine related distribution (c/f; Stoops, 2003) while the groundmass has a porphyric c/f related distribution (Figure 4, Table 1). The specific micro-features, such as the forming of iron-depleted zones around pores (Figure 4c), were revealed within the horizons with relatively low carbonate content.

\subsubsection{THE X-RAY TOMOGRAPHY OF THE AV HORIZON STRUCTURE}

On the basis of the tomographic analysis of separate cross-sections and resulting $3 \mathrm{D}$ reconstruction

Table 2. 3-D parameters based on the tomographic analysis of the top and the bottom parts of the crust.

\begin{tabular}{|l|c|c|}
\hline \multicolumn{1}{|c|}{ 3-D parameters } & Top & Bottom \\
\hline $\begin{array}{l}\text { Number of tomographic cross sections used in the } \\
\text { 3D-structure analysis }\end{array}$ & 173 & 151 \\
\hline Resolution $(\mu \mathrm{m})$ & 10.36 & 10.37 \\
\hline Total selected volume of sample $\left(\mathrm{mm}^{3}\right)$ & 73.98 & 64.58 \\
\hline Number of solid-phase objects per $1 \mathrm{~mm}^{3}$ & 40.34 & 195.18 \\
\hline Number of closed pores per $1 \mathrm{~mm}^{3}$ & 339.52 & 1110.18 \\
\hline Total number of pores per $1 \mathrm{~mm}^{3}$ & 391.84 & 1172.7 \\
\hline Number of contacts between objects per $1 \mathrm{~mm}^{3}$ & 105.79 & 511.26 \\
\hline
\end{tabular}




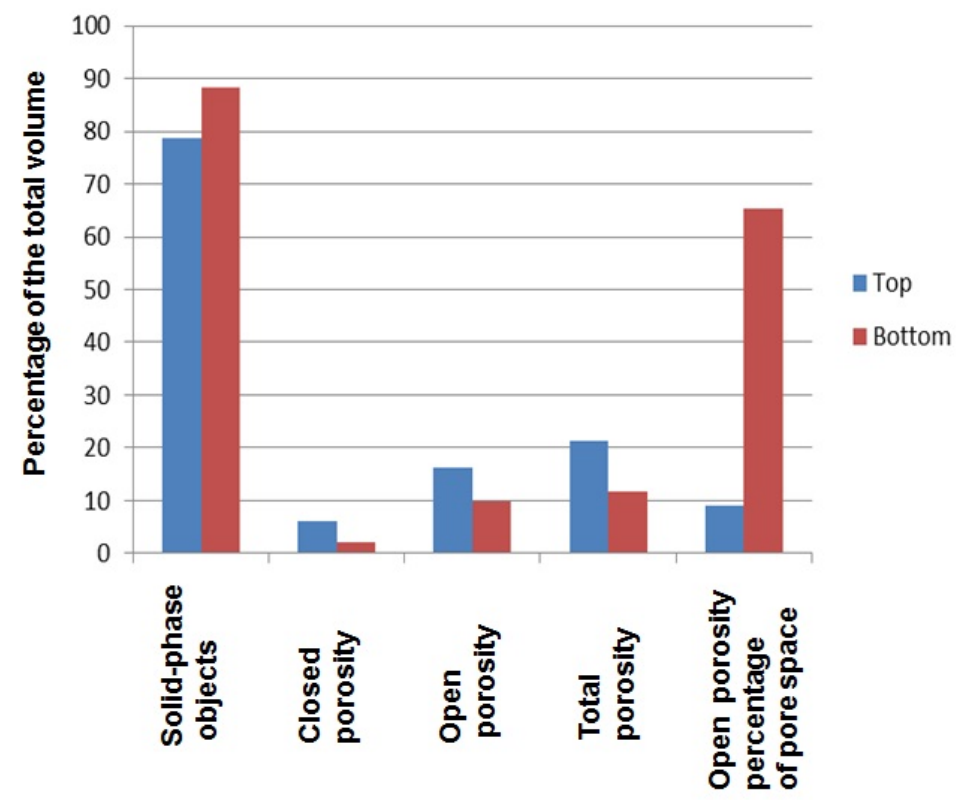

Figure 7 3-D parameters based on the tomographic analysis of the upper and the lower parts of the crust (volume \%).

of a sample from the Av horizon (Gobi, Mongolia), it was revealed that the sample is subdivided by a clear boundary into two parts (upper and lower) with different characteristics of pores and aggregates (Figure 5). These two parts were subjected to separate analyses (porosity and solid phase distribution) with subsequent comparison of the data obtained.

Calculations were carried out using the CTan programme for selected volumes as indicated in Figure 6. The selected 3-D shapes were 700 pixels $(7 \mathrm{~mm})$ in diameter and 150-170 pixels high. In the data presented below, the two parts of the horizon studied are also referred to as the 'top' and the 'bottom' of the vesicular crust.

Quantitative parameters of the top and the bottom of the vesicular crust are significantly different. In comparison to the lower part, the upper part has $2-3$ times lower numbers of pores, but the total porosity is 2 times higher, due to the larger pore size (Table 2, figures 7, 8).
There is a higher content of solid-phase units (1/ $\mathrm{mm}^{3}$ ) within the bottom of the Av horizon compared to its surface (Table 2). This corresponds to the higher looseness of solid phase units packs in the lower part of the horizon.

The upper part of the crust horizon is characterized by the presence of large vesicular pores that are isolated from smaller pores and each other. Their development was accompanied by the compaction of the solid phase: the content of micropores less than $50 \mu \mathrm{m}$ in size is very low (no more than $5 \%$ of the total pore volume) (Figure 8). Despite a high percentage of open porosity, vesicular pores are completely isolated from each other, as is shown at $10 \mu \mathrm{m}$ resolution (Figure 4c). The structure of the upper part of the crust resemblesd a compressed frozen foam. Its surface vesicles were are open and partly filled with soil particles (Figure 6). Micropores are prevailing (up to $70 \%$ of the total pore space) within the lower part, but almost absent within the upper part. In the lower part, no 


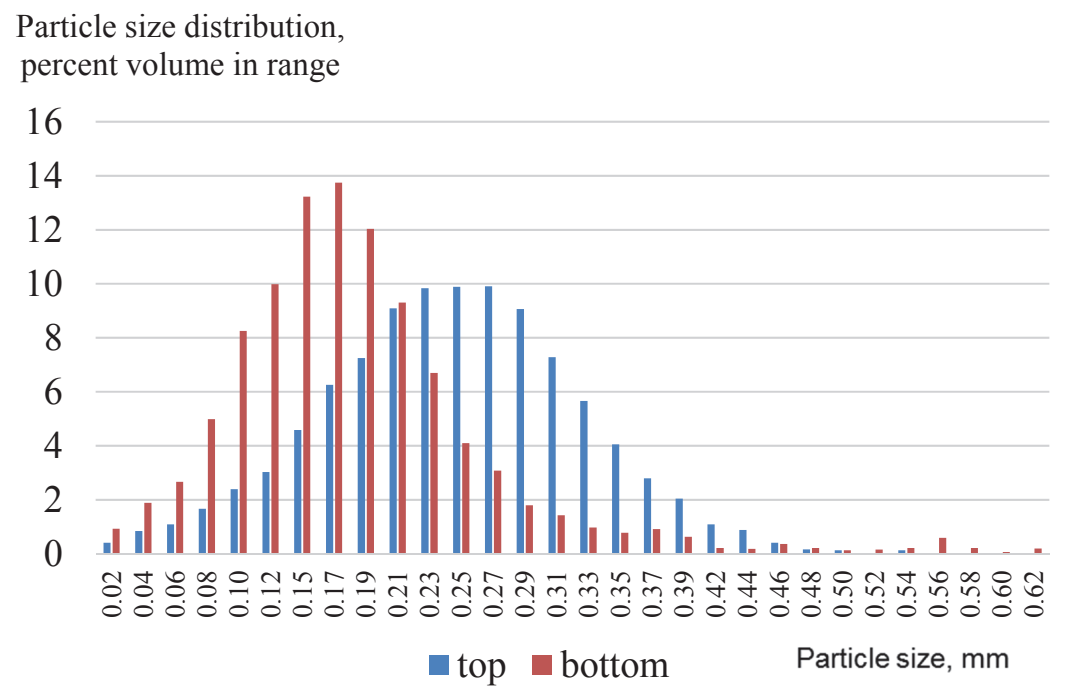

Figure 8 Average pore sizes and their proportion in the total pore space volume within the upper (blue) and the lower (orange) parts of the crust horizon.

pores larger than $250 \mu \mathrm{m}$ were found (Figure 8). The pore space connectivity values in the top and bottom parts are especially different. The $9 \%$ connectivity of pore space (Figure 7) is indicative of a very low infiltration capacity of the upper part of the crust horizon of desert soil.

\subsection{MACRO-, MIGRO-, AND SUBMIGROMORPHOLOGY OF DESERT VARNISH FILMS AND THEIR GHEMICAL COMPOSITION}

\subsubsection{MACROFABRIC OF DESERT VARNISH FILMS}

The upper sides of all studied rock fragments are covered by dark glossy desert varnish films (Figure 2). The lower sides of rock fragments are set into dense light-coloured vesicular crust horizon and had brown or red-brown (in the Mojave Desert samples) colour, through which the initial rock colour can be seen (in the Gobi Desert samples). In the field, the difference between the compared deserts was seen in a higher fissuring of coarse rock fragments of desert pavements in the Mojave Desert in comparison with that in the Gobi Desert.

\subsubsection{MICROFABRIC OF DESERT VARNISH FILMS}

Under the polarizing microscope, thin brown or reddish-brown films are seen in plain polarized light; they are isotropic in crossed polarized light. This type of desert varnish predominates among the studied samples. It can be found on rock fragments of different mineralogical composition, including basaltic lavas of the Cima volcanic field (Figure 9). The upper part of the desert varnish on this fragment consists of two different layers: an upper newly formed cryptograined silica layer and a lower ferriferous layer with moderately developed crumb microstructure (Figure 9e).

The thickness of the films increases above fissures dissecting felsic rocks (Figure $9 \mathrm{~b}, \mathrm{~d}$, e) both in the Gobi and Mojave deserts. In general, the thickness of such films and the frequency of their occurrence are higher in the Mojave Desert. In this desert, they penetrate deeper into the fissures of rock fragments. Under such films, the zones of iron accumulation in the form of iron pseudomorphs at the contact of light-coloured minerals (quartz and feldspars) are seen. A specific feature of desert 


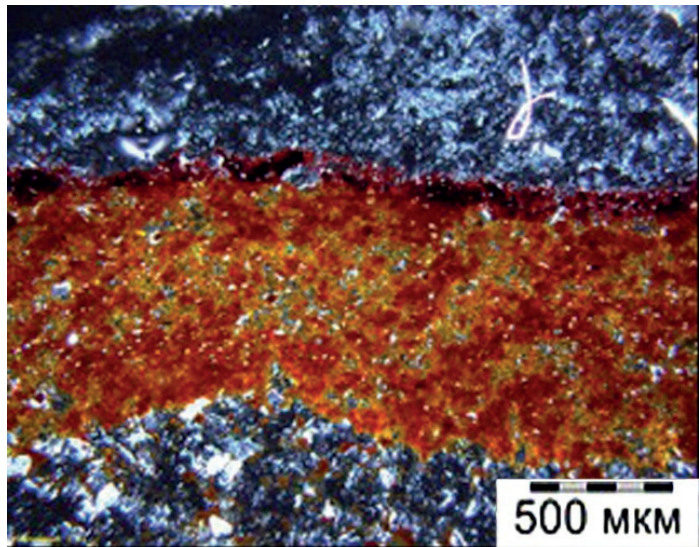

a)

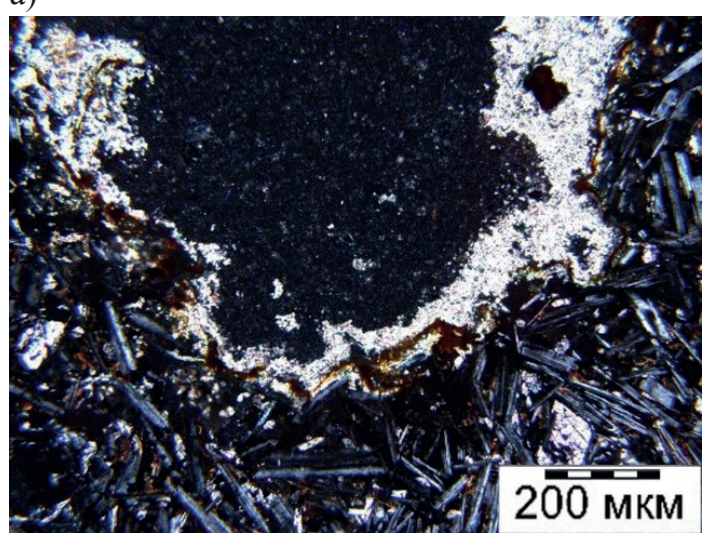

c)

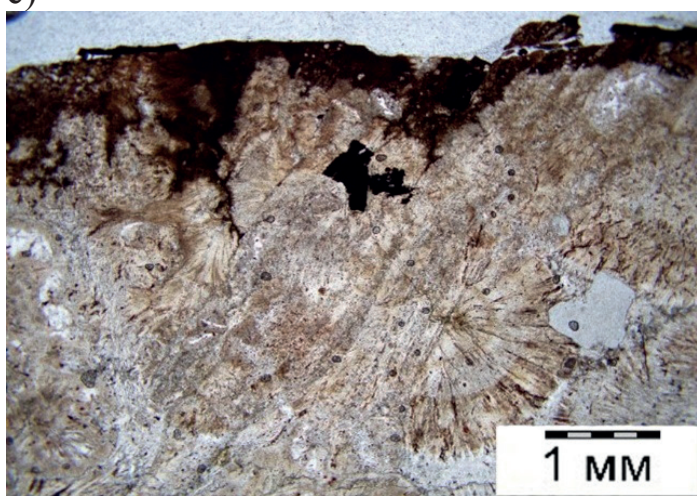

e )

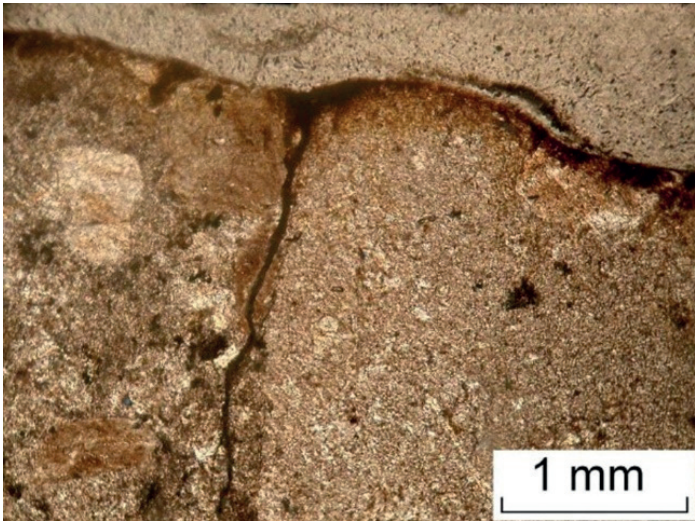

b)

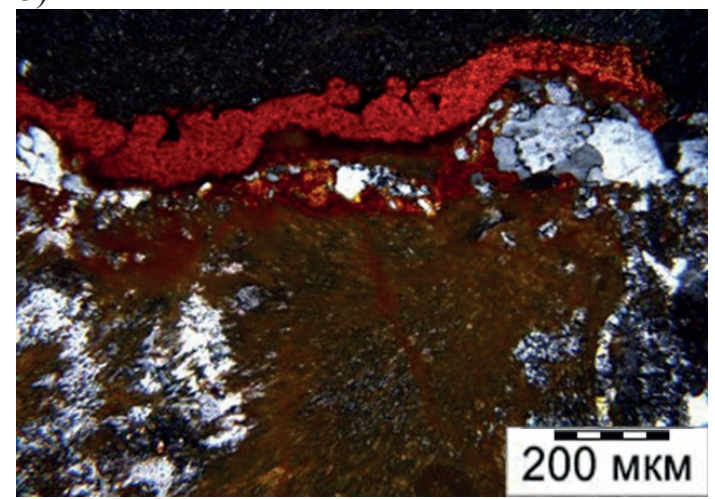

d)

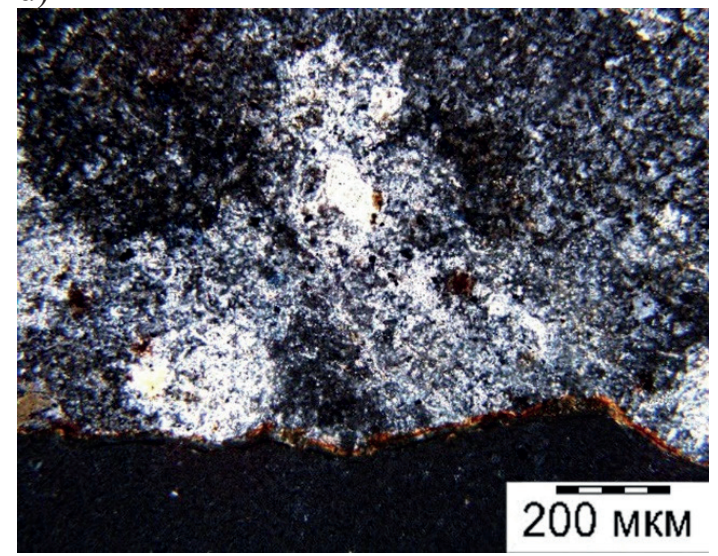

f)

Figure 9 The microfabric of desert varnish films on rock fragments from desert pavements of Gobi (a, b) and Mojave (c - f): (a) Si-MnFe film on sandstone (PPL); (b) thin film of desert varnish on the upper surface of a rock fragment from the desert pavement - the thickness of this ferruginous film is increased within microcavities, ferruginous compounds penetrate inside the rock fragment (PPL); (c) two-layered film on the upper surface of the fragment of lava (olivine basalt): the upper layer - relatively thick, fine-grained, silicatecarbonate; the lower layer - thin, ferruginous (the Sima Plateau, U.S.A.) (PPL); (d) thick multilayered ferruginous film on the surface of the rock fragment (aporhyolitic quartzite) with a fan-like penetration into the rock (PPL); (e) ferruginous film of varied thickness on the upper surface of the rock fragment (spherolithic rhyolite) with continuous desert varnish; ferruginous compounds penetrate inside the rock fragment along cracks (PPL); (f) thin anisotropic clay coating on the lower side of the rock fragment (ignimbrite) from the desert pavement (PPL). 
Table 3. The elemental composition of single-layered films of desert varnish in Mongolia and USA on different surfaces of rock fragments (mass \%).

\begin{tabular}{|c|c|c|c|c|c|c|c|c|c|c|c|}
\hline \multirow{2}{*}{ Loci } & \multirow{2}{*}{ Pit no. } & \multicolumn{5}{|c|}{ Film } & \multicolumn{5}{|c|}{ Cut rock under the film } \\
\hline & & $\mathrm{Fe}$ & Mn & $\mathbf{T i}$ & Si & $\overline{A l}$ & Fe & $\mathbf{M n}$ & $\mathbf{T i}$ & Si & $\mathbf{A l}$ \\
\hline \multicolumn{12}{|c|}{ Gobi (Mongolia) } \\
\hline \multirow{6}{*}{$\begin{array}{l}\text { Upper side } \\
\text { of stone }\end{array}$} & $10(1)^{*}$ & 3.69 & 0.72 & 0 & 21.34 & 4.24 & 3.38 & 0 & 0 & 32.93 & 3 \\
\hline & $10(2)$ & 5.07 & 0 & 0.26 & 18.41 & 6.22 & 1.36 & 0 & 0 & 27.75 & 10.23 \\
\hline & 213(1) & 4.21 & 0.84 & 0 & 18.94 & 4.21 & 2.1 & 0 & 0 & 35.83 & 2.43 \\
\hline & $213(2)$ & 2.49 & 1.82 & 0.22 & 21.76 & 5.56 & 1.37 & 0 & 0 & 34.87 & 6.2 \\
\hline & Lava $10(1)$ & 3.91 & 0 & 0.39 & 19.09 & 7 & 5.63 & 0 & 0.16 & 22.09 & 6.76 \\
\hline & Lava $10(2)$ & 2.82 & 0 & 0.69 & 15.37 & 3.73 & 5.36 & 0 & 0.26 & 20.12 & 6.35 \\
\hline \multirow{4}{*}{$\begin{array}{l}\text { Lower side } \\
\text { of stone }\end{array}$} & $10(1)$ & 1.7 & 0 & 0.27 & 16.35 & 4.08 & 0.68 & 0 & 0 & 28.21 & 5.62 \\
\hline & $10(2)$ & 2.3 & 0 & 0.18 & 13.97 & 5.72 & 0.73 & 0 & 0.17 & 19.79 & 5.1 \\
\hline & $213(1)$ & 2.81 & 0 & 0.39 & 17.99 & 5.78 & 0.7 & 0 & 0 & 26.99 & 6.86 \\
\hline & $213(2)$ & 0.98 & 0 & 0.21 & 19.09 & 3.83 & 0.42 & 0 & 0 & 27.19 & 6.59 \\
\hline \multicolumn{12}{|c|}{ Mojave (USA) } \\
\hline \multirow{6}{*}{$\begin{array}{l}\text { Upper side } \\
\text { of stone }\end{array}$} & Pan- & 3.64 & 0.91 & 0.26 & 22.83 & 6.36 & 0 & 0 & 0 & 27.8 & 4.3 \\
\hline & Pan-28(2) & 2.89 & 2.22 & 0.21 & 18.37 & 5.43 & 0 & 0 & 0 & 28.97 & 5.14 \\
\hline & Pan-28(3) & 2.51 & 0 & 0.12 & 11.97 & 5.64 & 0 & 0 & 0 & 30.42 & 4.78 \\
\hline & $\operatorname{Cim}(1)$ & 3.88 & 0.76 & 0.54 & 17.27 & 7.88 & 8.11 & 0 & 1.4 & 20.64 & 7.92 \\
\hline & $\operatorname{Cim}(2)$ & 5.16 & 1.28 & 0.9 & 15.91 & 7.38 & 5.64 & 0 & 1.91 & 21.68 & 9 \\
\hline & $\operatorname{Cim}(3)$ & 5.78 & 6.86 & 0.54 & 17.06 & 8.03 & 10.6 & 0 & 3.65 & 16.9 & 8.49 \\
\hline \multirow{6}{*}{$\begin{array}{l}\text { Lower side } \\
\text { of stone }\end{array}$} & Pan-28(1) & 3.16 & 0 & 0.19 & 16.7 & 5.4 & 0 & 0 & 0 & 27.8 & 4.3 \\
\hline & Pan-28(2) & 2.7 & 0 & 0 & 24.72 & 6.64 & 0 & 0 & 0 & 28.97 & 5.14 \\
\hline & Pan-28(3) & 2.42 & 0 & 0 & 23.18 & 7.2 & 0 & 0 & 0 & 30.42 & 4.78 \\
\hline & $\operatorname{Cim}(1)$ & 4.9 & 0 & 0.85 & 18.9 & 10.16 & 7.19 & 0 & 1.91 & 19.72 & 10.11 \\
\hline & $\operatorname{Cim}(2)$ & 5.51 & 0 & 0.86 & 18.33 & 9.55 & 9.23 & 0 & 3.59 & 14.18 & 6.6 \\
\hline & $\operatorname{Cim}(3)$ & 3.87 & 0 & 0.3 & 14.86 & 8.11 & 10.73 & 0 & 3.7 & 17.33 & 8.7 \\
\hline
\end{tabular}

* Different sampling loci on the same stones from desert pavement are indicated in parentheses. Lava in the Gobi Desert denotes a fragment of dark-coloured rock with vesicular surface from all sides. This rock fragment was present among other rock fragments in pit 10.

varnish films inside cavities in the basaltic lava is that they are covered by fine-grained silicates and carbonates (silicate-calcitic coatings) of presumably aeolian genesis (Figure 9c).

The surface of some rock fragments in the Mojave Desert is covered by discontinuous "spotty" desert varnish films. Under the microscope, these are thick red-coloured anisotropic films having a sharp contact with the underlying spherulitic rhyolite (Figure 9d). The optical properties of these films suggest the predominance of hematite in their composition.

The lower sides of rock fragments are plunged into the fine-earth vesicular crust horizon. The films on their surface are anisotropic and have the striated fabric typical of the iron-clayey micromass. The contact of these films with the dark-coloured olivine basalts (pit Cim) containing titanomagnetite and other iron minerals (Figure 9f) is especially distinct.

\subsubsection{SUBMICROMORPHOLOGY OF DESERT VARNISH FILMS}

Electron microscopy and microprobe analysis (tables 3, 4; Figure 9) also confirms a considerable similarity of desert varnish on the surface of rock fragments in both deserts. Most of the desert varnish films on convex and smooth parts of the 
Table 4. Element concentrations (wt.\%) in different parts of two-layered desert varnish films found in microlows on top sides of rock fragments of desert pavements in Mongolia and the United States.

\begin{tabular}{|c|c|c|c|c|c|c|c|c|c|c|c|c|c|c|c|c|c|c|}
\hline \multirow{2}{*}{ Pit no. } & \multicolumn{6}{|c|}{ Upper layer of the film } & \multicolumn{6}{|c|}{ Lower layer of the film } & \multicolumn{6}{|c|}{ Cut rock under the film } \\
\hline & Fe & Mn & $\mathbf{B a}$ & $\mathbf{T i}$ & $\mathbf{S i}$ & $\overline{\text { Al }}$ & $\mathrm{Fe}$ & Mn & $\overline{\mathbf{B a}}$ & $\overline{\mathbf{T i}}$ & $\mathbf{S i}$ & Al & $\mathrm{Fe}$ & $\mathbf{M n}$ & $\mathbf{B a}$ & $\mathbf{T i}$ & $\mathbf{S i}$ & Al \\
\hline \multicolumn{19}{|c|}{ Gobi (Mongolia) } \\
\hline $213(1)^{*}$ & 5.78 & 0.62 & 0 & 0 & 21.5 & 6.36 & 1.76 & 19.52 & 4.69 & 0 & 15.66 & 6.25 & 0 & 0 & 0 & 0 & 30.1 & 4.61 \\
\hline $213(2)$ & 10.8 & 2.09 & 0 & 0.36 & 23.2 & 7.76 & 0.72 & 3.76 & 0.81 & 0 & 33.13 & 4.18 & 0 & 0 & 0 & 0 & 39.28 & 3.42 \\
\hline 213(3) & 7.86 & 0.58 & 0 & 0 & 22.88 & 5.97 & 2.05 & 5.93 & 1.71 & 0 & 13.79 & 5.44 & 0 & 0 & 0 & 0 & 31.9 & 6.56 \\
\hline \multicolumn{19}{|c|}{ Mojave (USA) } \\
\hline Pan-28(1) & 15.95 & 1.51 & 0 & 0.47 & 16.1 & 8.43 & 1.3 & 19.32 & 4.39 & 0 & 9.53 & 5.39 & 0 & 0 & 0 & 0 & 32.08 & 6.52 \\
\hline Pan-28(2) & 8.5 & 1.95 & 0 & 0.22 & 15.1 & 6.77 & 0 & 17.21 & 3.24 & 0 & 12.95 & 5.51 & 0 & 0 & 0 & 0 & 30.33 & 4.9 \\
\hline Pan-28(3) & 5 & 0.38 & 0 & 0.24 & 18.33 & 3.61 & 1.08 & 11.33 & 2.49 & 0 & 10.8 & 6.44 & 0 & 0 & 0 & 0 & 30.6 & 4.17 \\
\hline $\operatorname{Cim}(1)$ & 9.35 & 0.47 & 0 & 0.42 & 18.08 & 8.7 & 3.29 & 14.08 & 1.71 & 0 & 14.5 & 7.63 & 8.1 & 0 & 0 & 1.4 & 20.64 & 7.92 \\
\hline $\operatorname{Cim}(2)$ & 11.89 & 1.15 & 0 & 0.85 & 20.28 & 7.01 & 0.86 & 7.2 & 0.87 & 0 & 13.63 & 7.26 & 11 & 0 & 0 & 3.7 & 21.68 & 9 \\
\hline
\end{tabular}

rocks are one-layered and consist of silica, manganese, and iron. Two-layered films are developed in the rock cavities (Figure 10). In the lower layer of two-layer films, Mn prevails and $\mathrm{Ba}$ is present, and in the upper layer Fe prevails and Ti appears. Furthermore, the composition of all the films of desert varnish does not depend on the composition of rock fragments, whose surface they cover (tables 3, 4).

\section{Discussion}

Combined micromorphological studies of desert varnish and the vesicular horizon of extremely arid soils developed within the ancient piedmont plains of the Mojave Desert and the Trans-Altai Gobi Desert have revealed a large complex of similar elements of microfabrics (Lebedeva and Shishkov, 2016).

The vesicular crusts are enriched in silt and clay particles due to aeolian transport and accumulation of such particles under rock fragments of desert pavement (after McDonald, 1994; McDonald et al., 2014). Additionally, physical weathering of proluvial sediments under alternating conditions of heating-cooling and wetness-dryness contribute to the silt and clay enrichment. The previous, caused these sediments to become increasingly silty (Cooke, 1970; Konischev, 1981), calcareous (due to secondary calcium carbonate accumulation, Glazovskaya, 1988) and sometimes saline. These factors are favourable for the development of vesicular porosity.

Several mechanisms of the formation of vesicular porosity are discussed in the literature:

- Displacement of soil air by an advancing wetting front (Springer, 1958; Dietze et al., 2012).

- Displacement of adsorbed air by rainwater (Gorbunov and Bekarevich, 1955; Lebedeva et al., 2009, 2016).

- Changes in calcium bicarbonate equilibrium $\left(\mathrm{Ca}\left(\mathrm{HCO}_{3}\right)_{2} \leftrightarrow \mathrm{CaCO}_{3}+\mathrm{CO}_{2}+\mathrm{H}_{2} \mathrm{O}\right)$ (Paletskaya et al., 1958).

Clayey and calcareous coatings in the pores of Av horizon on a microlevel were described for many topsoils of desert soils. They were also described for Cima plateau (Anderson et al., 2002). We relate the origin of clayey coatings to the local clay mobility under extremely alkaline conditions $(\mathrm{pH}>9)$ during the rainy season (Glazovskaya and Gorbunova, 2003). Calcareous coatings are formed due to precipitation of carbonates on the pore walls at the evaporation of the salt solutions entering from below (Figure 9c).

Microtopographic distribution of the soil pits also affects the degree of coating formation. Their maximal thickness was revealed within the soils 


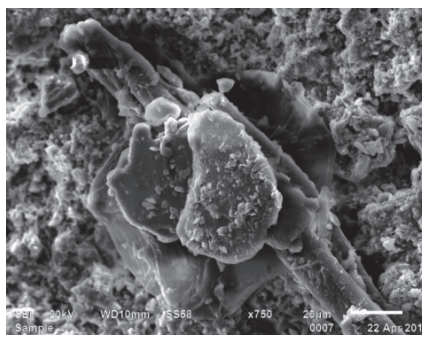

a)
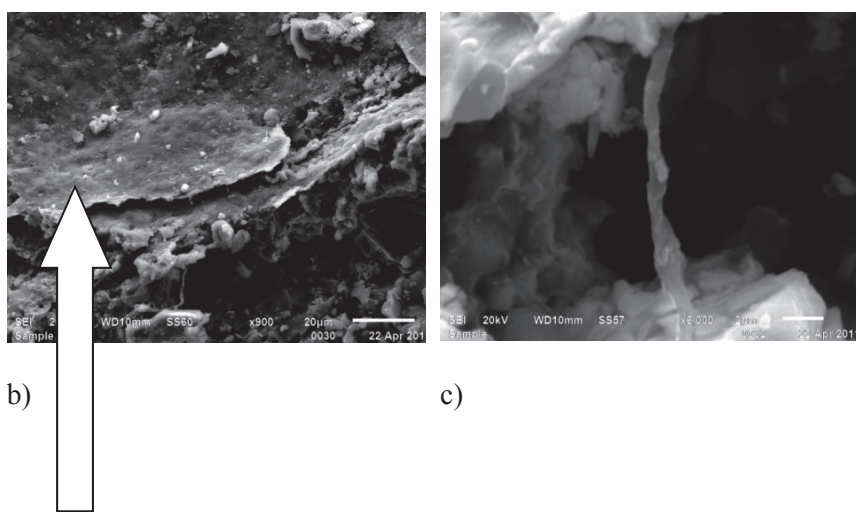

c)

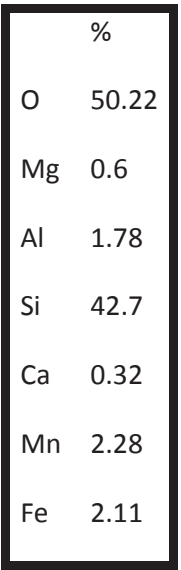

Figure 10 The biogenic and illuvial microfeatures of desert varnish within a cavity on the upper side of a rock fragment from the desert pavement (SEM, Gobi, pit 10): (a) microfossils under biotite layers; (b) Mn-Fe-Si two-layered illuvial film with filamentous bacteria underneath; (c) filamentous form of iron bacterium under an illuvial film of desert varnish; (d) elemental microprobe analysis of the central part of the film.

of the lower parts of microslopes, which confirms the possible lateral migration of salty solutions and materials in suspension. In any case, the presence of any coatings on the walls of vesicular pores in Av horizons makes them more temporally sustainable (Sullivan and Koppi, 1991; Turk and Graham, 2014).

Under extremely arid desert conditions, the amount of moisture falling onto the soil surface is insufficient for forming gravitational water flow. Water in desert soils is represented by capillary suspended, pellicular and hygroscopic moisture, according to Rode and Pol'skii (1961). Therefore, the vertical differentiation of soil profile is caused by upward rather than by downward flow of moisture. The data obtained by the authors on the composition of desert varnish films (present on rock fragments partly sunk into fine earth of the Av horizon) in the Mojave and Gobi deserts, allow an interpretation of desert varnish as a result of movement of pellicular (transitional between hygroscopic and capillary) moisture with dissolved forms of reduced iron and manganese $\left(\mathrm{Fe}^{2+}\right.$ and $\mathrm{Mn}^{2+}$ ) from the crust horizon up to the surface of desert pavement.

An extremely oxidative environment seems to prevail in desert soils during long dry periods (Perel'man and Kasimov, 1999). During shorter precipitation periods, anaerobic conditions develop within the crust horizon (Lebedeva et 


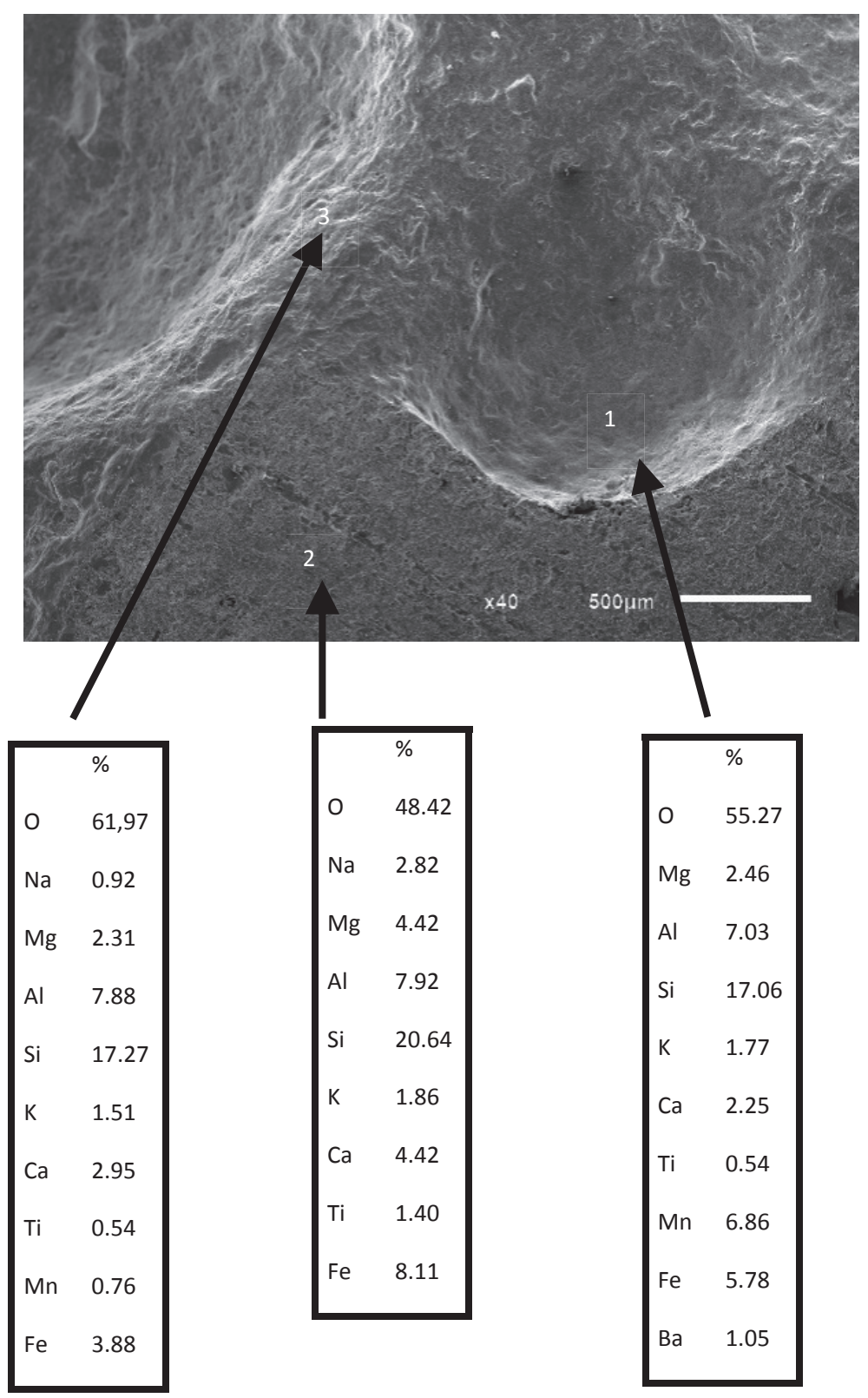

Figure 11 Elemental composition of desert varnish films (microprobe analysis) on olivine basalt (pit Sim), cross-section of the bubble cavity on the lava surface: 1 - thick varnish film; 2 - cut-rock; 3 - thin varnish film (SEM secondary electron mode, mass \%).

al., 2009). This is confirmed by the appearance of iron-depleted zones around of vesicular pores after several cycles of moistening and the burst of microbial processes (activity pulses) within the extremely arid conditions of Mongolian deserts (Gel'tser 1988, 1990). Anaerobic conditions are formed due to: the poor water conductivity of the crust horizon (Fox et al., 2009; Turk and Graham,
$2011,2014)$ and the poor solubility of oxygen in mineralized soil solutions (practically in brines), especially in summer, when the soil surface temperature exceeds $+60-+70^{\circ} \mathrm{C}$.

Extremely arid soils of Mongolia are characterized by climate-induced formation of solonchakous features (Evstifeev, 1977). Hence, desert soil solutions are saline, dominated by sulphates. In 


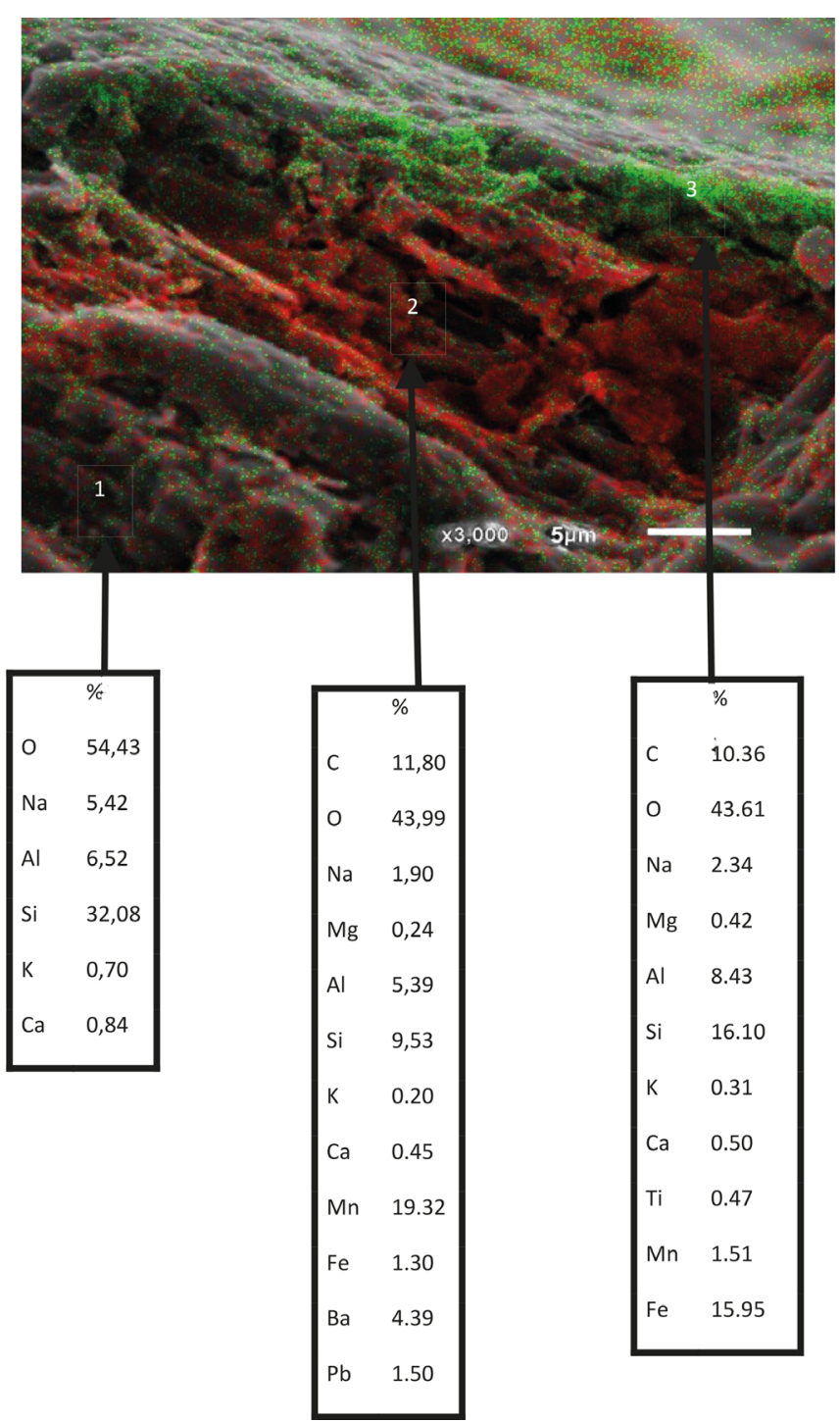

Figure 12 Element distribution in two-layered films of desert varnish on the surface of rock fragments from pit PAN-28 (Mojave) and microprobe analysis: 1-cut rock, 2-lower layer of the film, and 3-upper layer of the film (oblique view, SEM, mass \%).

this case, microorganisms oxidizing organic matter have to use sulphate ions from the soil solution as electron acceptors (Cypionka, 2000):

$$
\mathrm{SO}_{4}{ }^{2-}+\mathrm{OrgC} \rightarrow \mathrm{S}^{2-}+\mathrm{CO}_{2}
$$

Iron and manganese reduction within the crust horizon was confirmed by direct observations using the 'agar-covered fouling glasses' method (Lebedeva and Kutovaya, 2013). However, sulphate reduction with intermediate production of $\mathrm{FeS}$ and $\mathrm{MnS}$ has to be regarded as a hypothetical process:

$$
\mathrm{Fe}_{2} \mathrm{O}_{3} \rightarrow \mathrm{FeO} \rightarrow \mathrm{FeS}
$$

Barium accumulation within the film of desert varnish is an additional argument in support of sulphate reduction as an intermediate stage of the cryptosolodization process - solodization on the microlevel. 'Solodization' in Russian terms means the development of redoximorphic features in the presence of salts (Tursina, 1966; Golovanov et al., 2005). Barium is almost entirely immobilized in the presence of sulphates, while in the presence of sulphides $\mathrm{Ba}^{2+}$ is extremely soluble (Kasimov, 


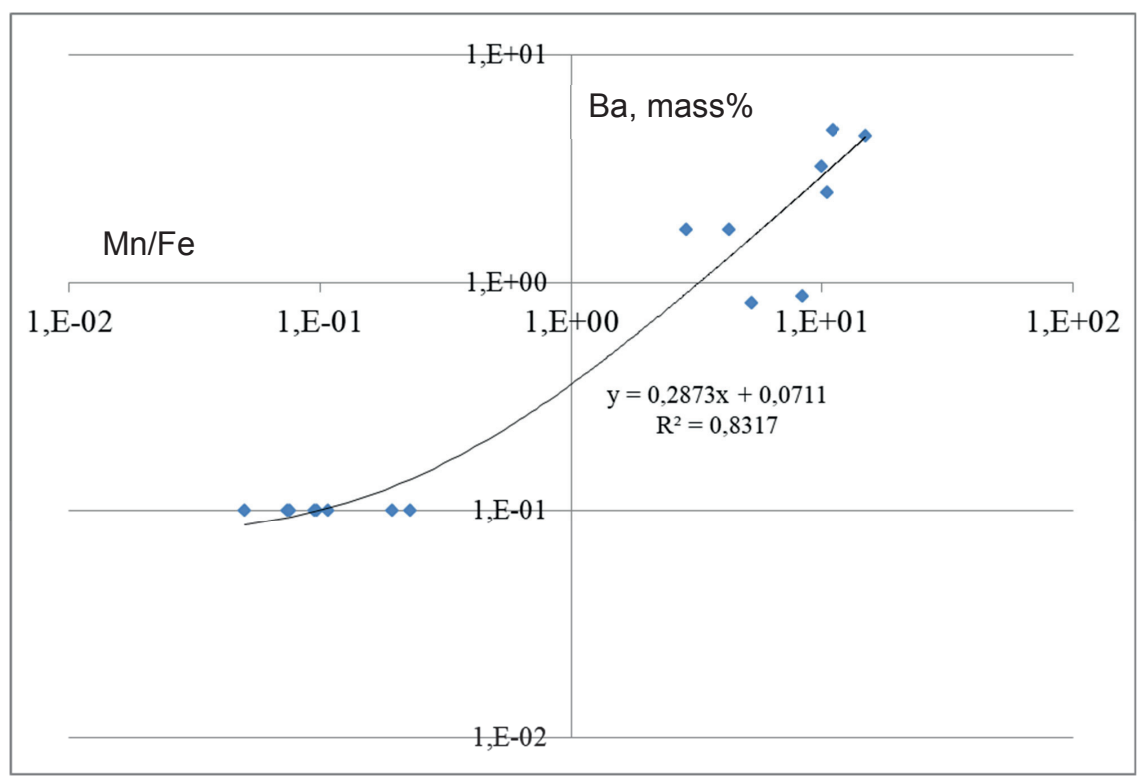

Relationship between the contents of $\mathrm{Ba}$ (mass \%) and the Mn/Fe ratio within the films of desert varnish of both deserts.

1988). Dissolved barium and manganese migrate with pellicular moisture flow towards the surface of desert pavement. The ions of $\mathrm{Mn}^{2+}$, as opposed to $\mathrm{Fe}^{2+}$, are mobile under neutral and weakly alkaline conditions, thereby causing mostly black colour of desert pavement due to the prevalence of Mn over Fe. Manganese has changed its rank from micro- to macro-element within the dark, almost black films of desert varnish.

The chemical composition of desert varnish does not depend on bedrock composition, but it depends on the microtopography of rock surfaces (figures 11, 12).

The exposed surfaces of rock fragments of desert pavements are covered mostly by silicate-ferruginous films, while micro-cavities in those rocks usually bear two-layered films: the lower layer with the prevalence of manganese and increased concentration of barium, and the upper layer with the prevalence of iron and accumulation of titanium (figures 12, 13, 14).
Similar features were earlier reported in deserts in the western USA, but without interpretation of their genesis. In addition to the suggested 'explosive' development of two-layered films after rainfall events (Golovanov et al., 2016), there is an alternative explanation of microlamination based on climate change (McFadden et al., 1986; Liu and Broecker, 2007, 2008; Dorn, 2009).

After a partial evaporation of moisture from the crust horizon, FeS oxidation leads to an intermediate production of sulphuric acid, lowering of $\mathrm{pH}$, bleaching around pores, migration of dissolved iron and titanium to the surface of desert pavement as well as to the middle horizon and lower sides of rock fragments, which is clearly manifested in red (not black) films (Figure 2).

The abrupt change of geochemical environments at the alternation of regimes of moistening of the crust horizon leads to the amorphization of layered aluminosilicates (Figure 3). 


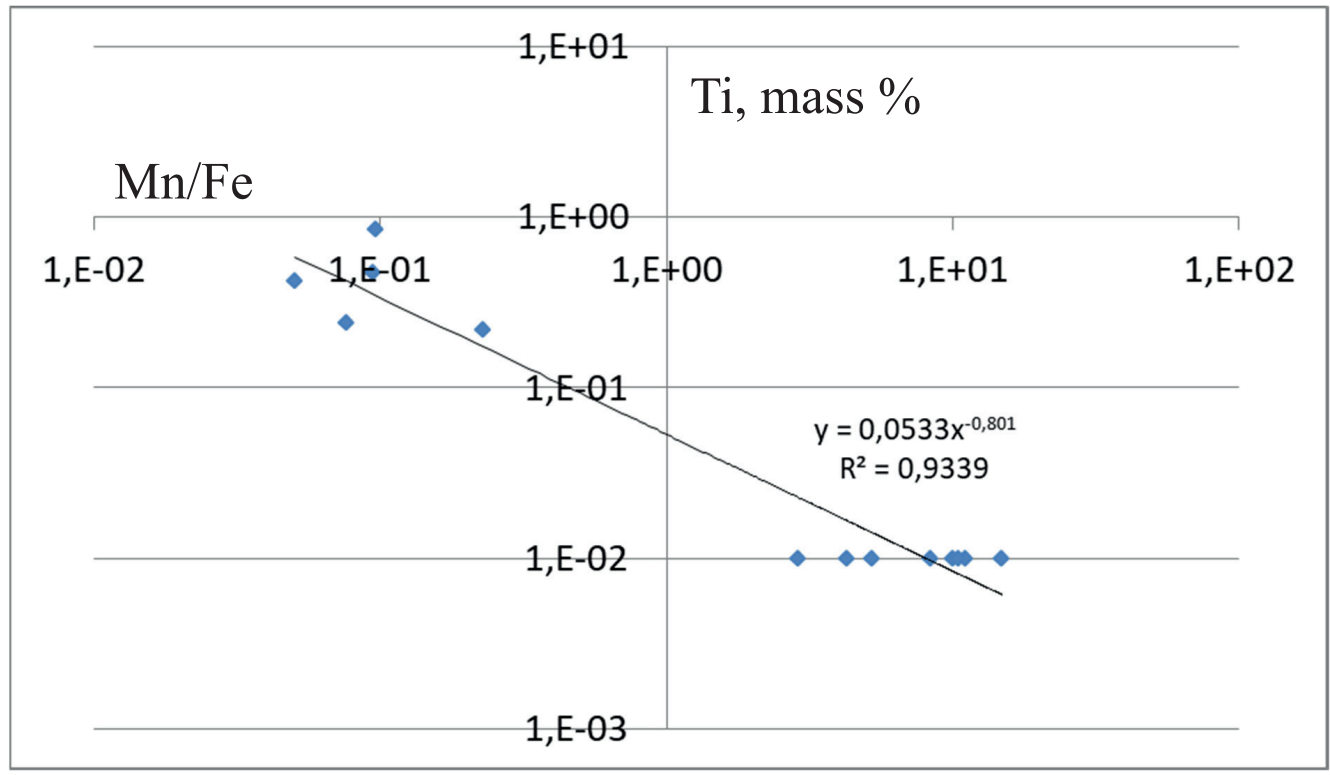

Figure 14 Relationship between the contents of $\mathrm{Ti}$ (mass \%) and the Mn/Fe ratio within the films of desert varnish of both deserts.

\section{Conclusions}

The present study on desert varnish and the vesicular horizon of extremely arid soils in the USA and Mongolia is based on a combined application of scanning electron microscopy, micromorphology and tomography. Micromorphological features show iron mobilization under anaerobic conditions in general (though with micro-aerobic zones), which include iron depletion pedofeatures around pores and ferruginous micro-concentrations. The upper black film on the surface of stony pavement contains an increased amount of manganese. The lower layer (with brownish-red colour), unlike the upper layer, is characterized by the absence of manganese. The surface double-layered films of desert varnish retain the same composition and $\mathrm{Fe} / \mathrm{Ti}$ and $\mathrm{Mn} / \mathrm{Ba}$ ratios independently from the initial composition of parent materials and geographical location of the study regions. We offer an explanation of both phenomena of desert pedogenesis - light-coloured crust horizon and dark-coloured desert varnish - based on a combined hydrophysical-biogeochemical mechanism that causes a burst of microbiological activity and physicochemical processes following rare, but heavy showers during the hot season. Despite its transitory character, the process, which we suggest to call 'cryptosolodization', includes five stages: (1) $\mathrm{Fe}, \mathrm{Mn}$ and sulphate reduction with mobilization of $\mathrm{Ba}^{2+}$ from $\mathrm{BaSO}_{4}$, (2) precipitation of $\mathrm{FeS}$ and migration of $\mathrm{Ba}^{2+}$ and $\mathrm{Mn}^{2+}$ to the stone surface, (3) coprecipitation of $\mathrm{Ba}$ and $\mathrm{Mn}$ at a combined oxygen-sorption barrier, (4) oxidation of $\mathrm{S}^{2-}$ to $\mathrm{SO}_{4}{ }^{2-}$ with mobilization of $\mathrm{Ti}^{2+}$ from $\mathrm{TiO}_{2}$ and (5) oxidation of $\mathrm{Ti}^{2+}$ and $\mathrm{Fe}^{2+}$ and their coprecipitation in the form of oxides $\mathrm{TiO}_{2}$ and $\mathrm{Fe}(\mathrm{OH})_{3}$.

In contrast to the accretion hypothesis, which explains the occurrence of desert varnish by atmospheric and even cosmogenic precipitation, we suggest that the development of desert varnish is caused by the ascending migration of film moisture containing manganese to the surface of desert pavement.

\section{Acknowledgements}

The study of soils from the Mojave Desert was supported by the Russian Science Foundation (project No. 14-27-00133). Part of the soils investigations on red deposits in the Gobi Desert were 
supported by the state assignment project No. 0148-2016-0003. Also, we used the Collective Use Centers devices of the IGRAS and the Dokuchaev Soil Science Institute.

\section{References}

Anderson, K., Wells, S., Graham, R., 2002, Pedeogenesis of vesicular horizons, Cima volcanic field, Mojave Desert, California: Soil Science Society of America Journal, 66(3), 878-887.

Blackburn, W.H., 1975, Factors influencing infiltration and sediment production of semiarid rangelands in Nevada: Water Resources Research, 11(6), 929-937.

Chizhikova, N.P., Evstifeev, Y.G., Pankova, E.I., 1988, Mineralogical composition of the silt fraction of desert soils of Mongolia: Pochvovedenie, 8, 44-54 [in Russian].

Cooke, R.U., 1970, Stone pavements in deserts: Annals of the Association of American Geographers, 60(3), 560-577.

Cypionka, H., 2000, Oxygen respiration by Desulfovibrio species: Annual Review of Microbiology, 54, 827-848.

Darwin, G., 1860, Bahia-Brazil. Habits of a Diodon, in The Voyage of the Beagle: Journal of Researches into the Natural History and Geology of the Countries Visited During the Voyage of H.M.S. Beagle Round the World: London, U.K., Murray, 12-13.

Dietze, M., Bartel, S., Lindner, M., Kleber, A., 2012, Formation mechanisms and control factors of vesicular soil structure: Catena, 99, 83-96.

Dorn, R.I., 2009, Desert rock coatings, in Parsons, A.J., Abrahams, A.D. (eds.), Geomorphology of Desert Environments: Amsterdam, The Netherlands, Springer, 153-186.
Dregne, H.E., 1976, Soils of arid regions: Amsterdam, The Netherlands, Elsevier, Developments in Soil Science, 6, 237 p.

Evstifeev, Y.G., 1977, Soils of extreme arid regions of the People's Republic of Mongolia (summary), in The Fifth Delegate Congress of the All-Union Society of Soil Scientists, Abstracts of Papers: Minsk, Belarus, 6, 172175 [in Russian].

Evstifeev, Y.G., 1980, Extreme arid soils of Gobi: Problemy osvoeniya pustyn, 2, 20-30 [in Russian].

Fox, S.-J., Mills, A.J., Poch, R.M., 2009, Micromorphology of surface crusts in the Knersvlakte, South Africa: Journal of Mountain Science, 6(2), 189-196.

Friedmann, E.I., Weed, R., 1987, Microbial tracefossil formation, biogenous, and abiotic weathering in the Antarctic cold desert: Science, 236(4802), 703-705.

Gel'tser, Y.G., 1988, Pseudocrystallization as a specific adaptive mechanism of Colpoda maupasi infusoria to unfavorable conditions in the extremely arid soils of the TransAltai Gobi, Mongolia: Tsitologiya, 30(11), 1386-1389.

Gel'tser, Y.G., 1990, Parameters of the biological activity used in soil studies: Pochvovedenie, 9, 47-60 [in Russian].

Gerasimova, M.I., Lebedeva, M.P., 2010, Topsoils - mollic, takyric and yermic horizons, in Stoops, G., Marcelinoa, V., Mees, F. (eds.), Interpretetion of Micromorphological Features of Soils and Regoliths: Amsterdam, The Netherlands, Elsevier, 351-369.

Glazovskaya, M.A., 1988, Geochemistry of Natural and Technogenic Landscapes in USSR: Moscow, USSR, Higher School, 327 p. [in Russian].

Glazovskaya, M.A., 2002, Biogeochemical weathering ofandesitic volcanic rocks in 
subantarctic periglacial conditions: Izvestiya Rossiyskaya Akademiya NaukIzv, 3, 39-48 [in Russian].

Glazovskaya, M.A., Gorbunova, I.A., 2003, Polygenesis of arid soils in Central Asia and Kazakhstan: Izvestiya Rossiyskaya Akademiya NaukIzv, 2, 36-42 [in Russian].

Golovanov, D.L., Lebedeva-Verba, M.P., Dorokhova, M.F., Slobodkin, A.I., 2005, Micromorphological and microbiological characterization of elementary soil-forming processes in desert soils of Mongolia: Eurasian Soil Science, 38(12), 1290-1300.

Golovanov, D.L., Lebedeva, M.P., Shishkov, V.A., Abrosimov, K.N., 2016, Combined biogeochemical mechanism of the development of desert varnish and vesicular horizon of desert soils (summary), in Proceedings All-Russia Conference, Geochemistry of landscapes (dedicated to the 100th anniversary of A.I. Perel'man): Moscow, Russia, Geographical Faculty, Moscow State University, 158-161. [in Russian].

Gorbunov, N.I., Bekarevich, N.E., 1955, Soil Crusting under Irrigation: Moscow, Russia, Izvestiya Akademiya Nauk, 70 p. [in Russian]. Gunin, P.D., 1990, Ecology of Desertification of Arid Ecosystems: Moscow, Russia, VASKhNIL, 354p. [in Russian].

Kasimov, N.S., 1988, Geochemistry of steppe and desert landscapes: Moscow, Russia, Lomonosov MSU Publishing, 254 p. [in Russian].

Konischev, V.N. , 1981, The Forming of Disperse Rocks Composition within Cryolithosphere: Novosibirsk, USSR, Nauka, 197 p. [in Russian].

Krinsley, D.H., Dorn, R.I., Tovey, N.K., 1995, Nanometer-scale layering in rock varnish: implications for genesis and paleoenvironmental interpretation:, The Journal of Geology, 103(1), 106-113.

Lebedeva, M.P., Kutovaya, O.V., 2013, Fabric of Topsoil Horizons in Aridic soils of Central
Asia: Spanish Journal of Soil Science, 3(3), 148-168.

Lebedeva, M.P., Shishkov, V.A., 2016, A Comparative Analysis of the Microfabrics of Surface Horizons and Desert Varnish in Extremely Arid Soils of the Mojave (USA) and Trans-Altai Gobi (Mongolia) Deserts: Eurasian Soil Science, 49(2), 163-179.

Lebedeva-Verba, M.P., Golovanov, D.L., Inozemtsev, S.A., 2009, Microfabrics of desert soils of Mongolia: Eurasian Soil Science, 42, 1204.

Lebedeva, M.P., Gerasimova, M.I., Golovanov, D.L., Yamnova, I.A., 2015, Extremely arid soils of the Ili Depression in Kazakhstan: Eurasian Soil Science, 48(1), 11-26.

Lebedeva, M.P., Golovanov, D.L., Abrosimov, K.N., 2016, Micromorphological diagnostics of pedogenetic, eolian, and colluvial processes from data on the fabrics of crusty horizons in differently aged extremely aridic soils of Mongolia: Quaternary International, 418(C), 75-83.

Liu, T., Broecker, W.S., 2007, Holocene rock varnish microstratigraphy and its chronometric application in the drylands of western USA: Geomophology, 84(1-2), 1-21.

Liu, T., Broecker, W.S., 2008, Rock varnish microlamination dating of late Quaternary geomorphic features in the drylands of the western USA: Geomophology, 93(3-4), 501-523.

McDonald, E., 1994, The relative influence of climatic change, desert dust, and lithological control on soil-geomorphic processes and hydrology of calcic soils formed on Quaternary alluvial-fan deposits in the Mojave Desert, California: Albuquerque, New Mexico, University of New Mexico, Ph.D. Dissertation, 383 p.

McDonald, E., Antinao, J. L., Gosse, J., 2014, Informal soil field trip guide: International Union for Quaternary Research, Project RAISIN Workshop Providence Mountains, 21. 
McFadden, L.D., Wells, S.G., Dohrenwend, J.C., 1986, Influences of Quaternary climatic changes on processes of soil development on desert loess deposits of the Cima Volcanic Field, California: Catena, 13(4), 361-389.

McFadden, L.D., McDonald, E.V., Wells, S.G., Anderson, K., Quade, J., and Forman, S.L., 1998, The vesicular layer and carbonate collars of desert soils and pavements: formation, age, and relation to climate change: Geomorphology, 24(2-3), 101-145.

McKeown, D.A., Post, J.E., 2001, Characterization of manganese oxide mineralogy in rock varnish and dendrites using X-ray absorption spectroscopy: American Mineralogist, 86(56), 701-713.

Mees, F., Singer, A., 2006, Surface crusts on soils/ sediments of the southern Aral Sea basin, Uzbekistan: Geoderma, 136(1-2), 152-159.

Mergelov, N.S., Goryachkin, S.V., Shorkunov, I. G., Zazovskaya, E.P., Cherkinsky, A.E., 2012, Endolithic pedogenesis and rock varnish on massive crystalline rocks in East Antarctica: Eurasian Soil Science, 45(10), 901-917.

Pagliai, M., Stoops, G., 2010, Physical and biological surface crusts and seals, in Stoops, G., Marcelino, V., Mees, F. (eds.), Interpretation of Micromorphological Features of Soils and Regoliths: Amsterdam, The Netherlands, Elsevier, 419-440.

Paletskaya, L., Lavrov, A., Kogan, S., 1958, Pore formation in takyr crust: Soviet Soil Science, 3, 245-250.

Pankova, E.I., 1992, Genesis of Salinization of Desert Soils: Moscow, Russia, All-Union V.I., Lenin Academy of Agricultural Sciences, 133 p [in Russian].

Pankova, E.I., Gerasimova, M.I., 2012, Desert soils: properties, pedogenic processes, and classification: Arid Ecosystems, 2(2), 69-77.

Perel'man, A.I., Kasimov, N. S., 1999, Geochemistry of landscape: Moscow, Russia, Astreay-2000, 730 p. [in Russian].
Perry, R.S., and Kolb, V. M., 2003, Biological and organic constituents of desert varnish: review and new hypotheses (summary), in The VII Conference of Society of Photographic Instrumentation Engineers - Instruments, Methods, and Missions for Astrobiology: Bellingham, U.S.A., Proceedings of the Society of Photographic Instrumentation Engineers, 5163, 202-217.

Perry, R.S., Lynne, B.Y., Sephton, M.A., Kolb, V. M., Perry, C.C., Staley, J.T., 2006, Baking black opal in the desert sun: the importance of silica in desert varnish: Geology, 34(7), 537-540.

Potter, R.M., Rossman, G.R., 1977, Desert varnish: the importance of clay minerals: Science, 196(4297), 1446-1448.

Potter, R.M., and Rossman, G. R., 1979, The manganese- and iron-oxide mineralogy of desert varnish: Chemical Geology, 25(1-2), 79-94.

Rode, A.A., Pol'skii, M.N., 1961, The soils of semideserts in the northwestern Caspian region and their amelioration (summary), in The Proceedings of the Forest Institute of AS USSR: Moscow, USSR, 56, 3-214 [in Russian].

Springer, M.E., 1958, Desert pavement and vesicular layer of some soils of the Desert of the Lahontan Basin, Nevada: Soil Science Society of America Journal, 22(1), 63-66.

Stoops, G., 2003, Guidelines for Analysis and Description of Soil and Regolith Thin Section: Madison, Wisconsin, U.S.A., Soil Science Society of America, $184 \mathrm{p}$.

Sullivan, L.A., Koppi, A.J., 1991, Morphology and genesis of silt and clay coatings in the vesicular layer of a desert loam soil: Australian Journal of Soil Research, 29(5), 579-586.

Turk, K.J., Graham, G.R., 2011, Distribution and properties of vesicular horizons in the Western United States: Soil Science Society of America Journal, 75(4), 1449-1461. 
Turk, K.J., Graham, C.R., 2014, Analysis of Vesicular Porosity in Soils using High Resolution X-Ray Computed Tomography: Soil Science Society of America Journal, 78(3), 868-880.

Tursina, T., 1966, The Microcomposition of Solodized Soils in Altai Krai: Pochvovedenie, 5, 7-18.

World Reference Base for Soil Resources (WRB), 2014, International Soil Classification
System for naming soils and creating legends for soil maps: Rome, Italy, International Union of Soil Sciences, Food and Agriculture Organization, $190 \mathrm{p}$.

Zolotokrylin, A.N., 2003, Climate-Depending Desertification: Moscow, Russia, Nauka, 246 p. [in Russian].

Zolotokrylin, A.N., 2008, Climate and Desertification, News of RAS: Geographic Series, 2, 27-35 [in Russian]. 